\title{
Turning points in migrants' labour market integration in Europe and benefit spillovers for Romania and Serbia: the role of socio-psychological credentials ${ }^{* 1}$
}

\author{
Grațiela Georgiana Noja ${ }^{2}$, Nebojša Petrovic ${ }^{3}$, Mirela Cristea ${ }^{4}$
}

\begin{abstract}
In this article we develop a two-fold analysis which captures the economic and socio-psychological coordinates in migrants' labour market integration into ten EU countries (EU-10), mostly targeted by immigrants (namely: Belgium, Denmark, Finland, France, United Kingdom, Germany, Austria, Sweden, Italy and Spain). The focus is on revealing the importance of socio-psychological credentials for an active labour market participation of immigrants, aiming to extrapolate factors (timespan 2000-2019), which can foster or complicate similar process in the future. Beside total immigration flows, we particularly entail the benefit
\end{abstract}

* Received: 14-09-2018; accepted: 07-12-2018

${ }^{1}$ Part of this work was conducted within the framework of STSM - Short-Term Scientific Mission, COST Action CA16111 “International Ethnic and Immigrant Minorities' Survey Data Network" (ETHMIGSURVEYDATA). We would like to thank the reviewers for their remarks that were extremely useful in framing the overall research.

${ }^{2}$ Associate Professor, West University of Timisoara, Faculty of Economics and Business Administration, East European Center for Research in Economics and Business, 16 Pestalozzi Street, 300115 Timisoara, Romania. Scientific affiliation: labour economics, globalization and regional economic integration, international migration, econometric modelling. Phone: +40744764002. E-mail: gratiela.noja@e-uvt.ro. Website: https://feaa.uvt.ro/ro/vezi-profilutilizator/gratiela.carica. (corresponding author).

3 Professor, University of Belgrade, Faculty of Philosophy, Čika-Ljubina 18-20, 11000 Beograd, Serbia. Scientific affiliation: reconciliation, social issues, migrations, peace studies, inequalities. Phone:+381113206166.E-mail:npetrovi@f.bg.ac.rs. Website: https://www.researchgate.net/ profile/Nebojsa_Petrovic3, http://www.f.bg.ac.rs/cv/PENE_228b.pdf.: .

4 Professor, University of Craiova, Faculty of Economics and Business Administration, Center for Banking and Financial Research, 13 A I Cuza Street, 200585 Craiova, Romania. Scientific affiliation: macroeconomic research; insurance, pension funds. Phone: +40-740-310-520. E-mail: mirelas.cristea@gmail.com. Website: http://feaa.ucv.ro/one/index.php?option=com_ contentbuilder\&view $=$ details\&Itemid $=776 \&$ lang $=$ ro. 
spillovers for Serbia and Romania in their migration challenges towards EU-10. A set of methods and macro-econometric models, based on spatial analysis, crosssectional analysis and structural equations modelling, was applied on the balanced panel formed by EU-10. The results highlight that an increased participation in society, community and improved living standards satisfaction (subjective wellbeing) positively reverberate on migrant integration into host economies since it tends to upsize the employment rate of the foreign population. The opposite, a negative impact is induced by social exclusion and reduced job security, while material deprivation also significantly diminishes the employment opportunities of foreign population and their active labour market integration.

Key words: immigrants, labour market integration, unemployment, European strategies, macro-econometric modelling

JEL classification: F22, F63, H19, J21, J24

\section{Introduction}

International migration represents a major challenge for Europe, in the framework of globalization and regional integration, being widely shaped by the economic and socio-psychological features related to natives' and migrants' wellbeing, the geo-political context and increased interdependencies between the economies. Moreover, labour mobility within the European Union (EU) is a fundamental pillar of the European economic integration process, so as its limitation or the discrimination of the foreign population tends to contradict the community construction itself. Nevertheless, the natives' reluctance towards the immigrants in the main receiving economies and the large scale of this phenomenon have generated important debates and decisions globally, whilst the EU is currently confronting with disintegration as a follow up of Brexit, migration remaining one of the key themes on the ongoing negotiation agenda.

The research on migrants' labour market integration into host countries with a specific focus on the EU needs to be strengthened with comprehensive studies analysing economic immigration flows in Europe that entail the importance of socio-psychological challenges, faced especially by newly arrived migrants in order to provide consistent empirical evidence for developing better immigration and integration policies. While previous studies focus on migration effects (e.g. Betz and Simpson, 2013), we consider that these consequences cannot be considered independent from the migration determinants and specific integration policies that are tightly related to the socio-psychological features of both natives and immigrants and their wellbeing. Hence, our research provides an integrative framework of analysis on the role of economic and socio-psychological credentials for migrants' labour market integration in ten EU countries (EU-10) that are mostly targeted by immigrants (namely Germany, the United Kingdom, France, Austria, Sweden, Italy, Spain, Belgium, Denmark and Finland), with specific focus on immigrants from Romania and Serbia. 
Compared to previous studies (Björnsson et al., 2018; Fong and Guo, 2018; Kogan et al., 2018), this paper focuses on analysing both migration indicators, and other socio-psychological, economic and labour market specific indicators, based on data for EU-10 migrant receiving countries, with the grasp on two scenarios: before and after introducing socio-psychological variables. The analysed period is 2000-2019 (relying on 2000-2016 history data), with a sub-sample for 2016 (cross-section).

Thus, our scientific endeavour brings additional evidence to attest the following hypotheses: H1. There is a positive direct relationship between the immigration flows and the labour market performance in EU-10 (before introducing sociopsychological variables); H2. An increase of subjective wellbeing (life satisfaction and human development) induces significant positive impacts on migrants' labour market integration, while material deprivation has opposite consequences (after introducing socio-psychological variables); H3. An increased participation in society and community (attendance to religious services, to political parties' meetings, trade unions) and improved living standards satisfaction positively reverberate on migrant integration into host economies, while social exclusion, job insecurity and material deprivation have significant negative effects on migrants' labour market integration.

Therefore, the impact of the proposed research is reflected through a set of new specific tailored ways, policies and strategies that can be adopted and implemented by the policy makers across Europe to cope with large inflows of labour immigrants, so as to discard potential negative spillovers and to enhance positive credentials that will be in the benefit of migrants, natives and the entire society.

The paper is structured on four major parts. The issues relating to the determinants and essential features of the migrants' integration process were outlined first. The second part comprises the research methodology, mainly the methods applied for macro-econometric models estimations. The data used and the empirical analysis are further detailed, with a particular focus on key indicators and the research results. The last part entails the research implications and concluding remarks.

\section{Literature review}

Short-term and long-run impacts of migration, which may vary in magnitude, are extensively determined by labour and capital flexibility and the ability of labour markets to adjust in the short and longer term. In line with what the theory predicts, numerous studies (e.g. Barbu and Boitan, 2018) point out that international migration generates complex economic and social consequences upon migrant sending and receiving countries.

Thus, the literature on immigrants' labour market integration reveal the importance of employment opportunities and low unemployment risks as essential coordinates 
for their inclusion and welfare contribution. However, immigrants often face significant lower chances of being employed than natives (Huber, 2015), and thus a substantial number of studies have centred on individual characteristics favouring or hindering immigrants' labour market integration, such as educational background (Borjas, 2000; Chiswick and Miller, 2014), age at migration (Goldner and Epstein, 2014; Igarashi, 2019), cultural or linguistic resemblances (Chiswick and Miller, 2014).

The integration processes are extremely complex and have two essential pillars, namely immigrants (with their abilities and characteristics), and the host society (in terms of interactions with newly arrived migrants and related institutions). Newly arrived migrants face many obstacles in terms of changes and successful integration into the labor market. These obstacles include, mainly, language barriers, difficulties in officially recognizing the qualifications and skills acquired in the country of origin, limited social and professional networks through which they can find a job.. Moreover, they confront with discrimination from the employers "on the hiring preferences and wage payments of employers", as Walkowitz (2019: 140) found. Also, there are findings related to competition and reluctance of immigrants from the natives (Strijbis and Polavieja, 2018), as ethnic and racial discrimination. Withal, the longer time immigrants become to discriminate the newly arrived immigrants, distinctive policies for native people and immigrants being necessary (Fong and Guo, 2018).

The institutions involved in the integration migrants' process are comprising two broad categories: (i) general public institutions, such as the education system or the institutional labor market arrangements in host countries, which can facilitate, restrict or even exclude access or outcome for newcomers; the functioning of these general public institutions and the possible adjustment in terms of opening up to diversity are therefore of decisive importance in the integration process; (ii) specific institutions to different immigrant groups, such as religious or cultural ones, which can be accepted as an integral part of the host society, close to those of native groups, or which may be isolated or unknown and, thus, excluded; and, in this case, their importance in the integration process and migrants inclusion is foremost. Huber (2015: 1) highlights that ,the sending country structure of immigrants to a country, its ethnic diversity and its wage bargaining institutions as well as product market regulation are the most important national institutions impacting immigrants' labour market integration".

Migrants' inclusion on the European labour market is essential for their effective integration into host societies, and for ensuring the positive effects of migration on the European economy. These aspects entail the full use of migrants' skills and the recognition of their economic potential, especially in terms of their contribution to the shortage of capabilities in certain sectors at all levels of qualification. Ensuring programs by which migrants can certify their educational and professional skills 
by which they are recognized and validated in the host country, and receive the appropriate training is a fundamental step for migrants' integrating as a whole, but especially, for generating a positive economic impact on host economies.

However, the energy for every activity in social communities is given by people, actors of activities and members of the involved groups. Without considering these energies, our predictions are not good enough, even in the field of economics, as shown by people who, for the inclusion of psychological factors in the field of economics, even received Nobel Prizes for economic: Daniel Kahneman (2002) and Richard Thaler (2017). Kahneman and Tversky (1979) showed that human activity cannot be explained by models that do not include human "flaws" such as subjective expectations and willingness to risk, explained in their Prospect theory. And many studies of inequality indicate there is more likely to people to endure deprivation than inequality (Milanovic, 2010), the phenomenon which many sociologists and psychologists explain using concept of relative deprivation (Walker and Pettigrew, 1984). It occurs when people compared with some close standard, and it is subjectively more important than absolute deprivation. This is, certainly, very important for the explanation of behavior of migrants who are coming to much more developed host countries.

In that vein, Van Praag (1971) use the concept of welfare function of income, which shown that people create "preference shift" after their incomes increase, which make them victims of a "hedonic treadmill" (Brickman and Campbell, 1971) of continuously changing preferences and satisfactions. Those and other factors determine peoples' well-being and life satisfaction. Besides, "immigrants and ethnic minorities tend to have lower life satisfaction than majority populations" (Knies et al., 2016: 110) due to disintegration and displacement in case of the young immigrants, and the lastingness of discrimination for the adults ones. Moreover, "people dissatisfied with life have a greater intention to migrate", life satisfaction becoming "a mediator between individual socioeconomic variables and macroeconomic conditions" and people's intention to emigrate (Otrachshenko and Popova, $2014: 47)$.

In the specific circumstances of meeting of members of two or more different cultures, there are many potential obstacles on the path to a harmonious, multicultural society. Members of host societies might react with anxiety that can produce prejudices, stigma and discrimination toward newcomers. Betz and Simpson (2013) found that overall effects of migration on natives' happiness are very low. On the other side, migrants have not so easy task to start the process of adapting to a different culture. Migrants' involvement in political and social participation would foster their integration within host country, however due to constraints related to "time and knowledge", high-skilled people are more liable to entail in such of associations than low-skilled immigrants (Voicu and Vlase, 2014). Cultural psychologist developed many models, but the most known is Berry's 
classification of acculturation strategies (1997), which will finish in integration, assimilation, separation or marginalization. The final or the dominant outcome of the acculturation will also affect all socio-psychological variables we presented.

\section{Methodology}

In order to cover for data benchmarking between countries, respectively to discard variations and associated differences, we have used the standardisation method in the first stage of the research. This method allowed a proper development of composite indicators $\left(y_{i}\right)$, suitable for analysing the values for each country by reference to the values of other countries considered within the panel, according to the equation (1).

$$
y_{i}=\frac{x_{i}-\text { mean }}{s d}
$$

where: $x_{i}$ denotes crude values of the indicator; $s d$ is the standard deviation (OECD, 2005).

To assess specific ways of labour market integration of immigrants into host economies, in the second stage of the research, we have developed a complex general model processed through spatial analysis (SAR and SE models), and other two estimation methods, namely the robust regression (RREG) (with Cook's D, Huber and Biweight iterations), and panel corrected standard errors (PCSE). Spatial analysis was mainly used because our focus was to examine the performances achieved by the neighbouring locations (spatial spillovers) in influencing the overall migrant integration outcomes of EU-10 countries.

Therefore, to see if the observations are grouped together or randomly spread, we've hereinafter applied the two spatial analysis models estimated through the maximum likelihood method (MLE), with a general configuration described by equations 2a, 2b (Viton, 2010):

Spatial lag models:

$$
y=\lambda W y+X \beta+u
$$

Spatial error models:

$$
y=X \beta+u, u=p W u+v
$$

where: $W$ is the inverse distance weights matrix, $y$ is the dependent (outcome) variable, $\mathrm{X}$ represents the explanatory (independent) variables, $\lambda$ and $\rho$ are scalars 
that measure the dependence of $y_{i}$ on nearby $y$ and the spatial correlation in the errors, $u$ represents the error term (spatially correlated residuals), $v$ captures independent and identically distributed disturbances.

In SAR model, "the spatially lagged dependent variable (ER_F, respectively UR_F) captures the spatial dependence between the cross sectional unit" (Glass et al., 2012: 2), and includes employment levels for the foreign population in neighbouring locations as an additional explanatory variable. In SE model, the spatial autocorrelation term entails the spatial dependence, thus the SE model controls for autocorrelation in both the dependent and independent variables, being more robust. Thus, the general model for migrants' labour market integration takes the form of a multiple regression model with panel data, but reconfigured through spatial procedures (equations $3 \mathrm{a}, 3 \mathrm{~b}, 3 \mathrm{c}$ ):

$$
\begin{aligned}
& E R_{-} F_{i t}\left(U R_{-} F_{i t}\right)=\beta_{0}+\beta_{1} G D P_{-} \operatorname{cap}_{i t}+\beta_{2} E D U_{-} S_{i t}+ \\
& +\beta_{3} E D U_{-}+\beta_{4} B E R D_{i t}+\beta_{5} A L M P S_{i t}+\beta_{6} P L M P s_{i t}+ \\
& +\beta_{7} P O V_{-} R_{i t}+\beta_{8} G i n i_{i t}+\beta_{9} I M I G_{-} R O_{i t}+\beta_{10} I M I G_{-} R S_{i t}+\varepsilon_{i t} \\
& E R_{-} F_{i t}\left(U R_{-} F_{i t}\right)=\lambda W E R_{-} F_{i t}+\beta_{1} G D P_{-} c a p_{i t}+\beta_{2} E D U_{-} S_{i t}+ \\
& +\beta_{3} E D U_{-} T_{i t}+\beta_{4} B E R D_{i t}+\beta_{5} A L M P S_{i t}+\beta_{6} P L M P s_{i t}+\beta_{7} P O V_{-} R_{i t}+ \\
& +\beta_{8} G i n i_{i t}+\beta_{9} I M I G_{-} R O_{i t}+\beta_{10} I M I G_{-} R S_{i t}+\varepsilon_{i t} \\
& E R_{-} F_{i t}\left(U R_{-} F_{i t}\right)=\beta_{0}+\beta_{1} G D P_{-} c a p_{i t}+\beta_{2} E D U_{-} S_{i t}+\beta_{3} E D U_{-} T_{i t}+ \\
& +\beta_{4} B E R D_{i t}+\beta_{5} A L M P S_{i t}+\beta_{6} P L M P S_{i t}+\beta_{7} P O V_{-} R_{i t}+ \\
& +\beta_{8} G i n i_{i t}+\beta_{9} I M I G_{-} R O_{i t}+\beta_{10} I M I G_{-} R S_{i t}+p W \varepsilon_{i t}+v
\end{aligned}
$$

where the variables of each equation are presented into Appendices, Table A1.

After introducing the socio-psychological variables, the model becomes (equation 4):

$$
\begin{aligned}
& E R_{-} F_{i t}\left(U R_{-} F_{i t}\right)=\beta_{0}+\beta_{1} I M I G_{-} R O_{i t}+\beta_{2} I M I G_{-} R S_{i t}+\beta_{3} \text { Gini }_{i t}+\beta_{4} H D I_{i t}+ \\
& +\beta_{5} \operatorname{Re} p_{-} \text {Life_satisf } i t+\beta_{6} G D P_{-} \text {cap } i t \\
& +\beta_{7} M a t_{-} \text {depriv }_{i t}+\beta_{8} E D U_{-} S_{i t}+ \\
& +\beta_{9} E D U_{-} T_{i t}+\beta_{10} B E R D_{i t}+\beta_{11} A L M P s_{i t}+\beta_{12} P L M P S_{i t}+\beta_{13} P O V_{-} R+_{i t} \varepsilon_{i t}
\end{aligned}
$$

Because a part of the socio-psychological variables used in processing the migrant integration models were captured from European Quality of Life Survey 2016 (Eurofound), with data at the level of 2016, in the third stage of our research, we developed a cross-section model for 2016 for assessing the labour market integration (ER_F, UR_F), and immigration impacts through socio-psychological aspects, measured for EU-10 destination countries, with the following configurations (equations 5 and 6): 
$E R_{-} F_{i t}\left(U R_{-} F_{i t}\right)=\beta_{0}+\beta_{1}$ Att_relig_serv ${ }_{i t}+\beta_{2}$ Voluntar_educ $_{i t}+$

$+\beta_{3} J_{o b}$ sec $_{i t}+\beta_{4}$ Soc_exclus $_{i t}+\beta_{5}$ Job_discreditt $_{t t}+\beta_{6}$ Livingstand_satisf $_{i t}+$

$+\beta_{7} E D U_{-} T_{i t}+\beta_{8} A P L M P S_{i t}+\beta_{9}$ Att_meet_political ${ }_{i t}+\varepsilon_{i t}$

$I M I G$ total $(R O, R S)_{i t}=\beta_{0}+\beta_{1}$ Att_relig_serv $(\text { Att_meet_political })_{i t}+$

$+\beta_{2}$ Voluntar_educ $_{i t}+\beta_{3} J_{o b}$ sec $_{i t}+\beta_{4}$ Soc_exclus $_{i t}+\beta_{5} J_{0} b_{-}$discredit $t_{i t}+$

$+\beta_{6}$ Livingstand_satisf $_{i t}+\beta_{7} E D U_{-} T_{i t}+\beta_{8} A P L M P s_{i t}+\varepsilon_{i t}$

At the core of our spatial models lies the inverse distance weights matrix (rowstandardized) (W), with the following characteristics: 2000-2019 sample - dimension: 200x200; distance band: $0<\mathrm{d}<=16000$; friction parameter: 1; minimum distance: $0.0 ; 1^{\text {st }}$ quartile distance: 0.3 ; median distance: $0.9 ; 3^{\text {rd }}$ quartile distance: 1.7; maximum distance: 7.5; largest minimum distance: 0.78 ; smallest maximum distance: $3.81 ; 2016$ cross-section - dimension: 10x10; distance band: $0<\mathrm{d}<=16000$; friction parameter: 1 ; minimum distance: $0.0 ; 1^{\text {st }}$ quartile distance: 0.4 ; median distance: $0.9 ; 3^{\text {rd }}$ quartile distance: 2.9 ; maximum distance: 5.1 ; largest minimum distance: 1.74 ; smallest maximum distance: 3.32 .

The presence (or absence) of spatial autocorrelation is tested through Patrick Moran (Moran's I) test by equation (7) (Viton, 2010).

$$
I=\frac{R}{\sum_{i} \sum_{j} \omega_{i j}} \frac{\sum_{i} \sum_{j} \omega_{i j}\left(x_{i}-\bar{x}\right)\left(x_{j}-\bar{x}\right)}{\sum_{i}\left(x_{i}-\bar{x}^{2}\right.}
$$

where $\omega_{i j}$ are the elements of the spatial weights matrix $W$ (row standardized), $R$ is the number of regions with associated neighbours (spatial units indexed by $i$ and $j$ ), $x$ is the variable of interest, $\bar{x}$ is the mean of $x$.

We've also applied bootstrap sampling and estimation on spatial models, since it ,allows assigning measures of accuracy (defined in terms of bias, variance, confidence intervals, prediction error or some other such measure) to sample estimates" (Efron and Tibshirani, 1993), thus providing consistent estimates.

Finally, on the fourth stage, a series of SEM (Structural Equations Modelling) models estimated through the MLE were applied to enforce and reconfirm spatial and macro-econometric models, with the general configurations from Figure 1. The variables of the SEM model are described into Appendices, Table A1. 
Figure 1: General configuration of the SEM model, 2000-2019

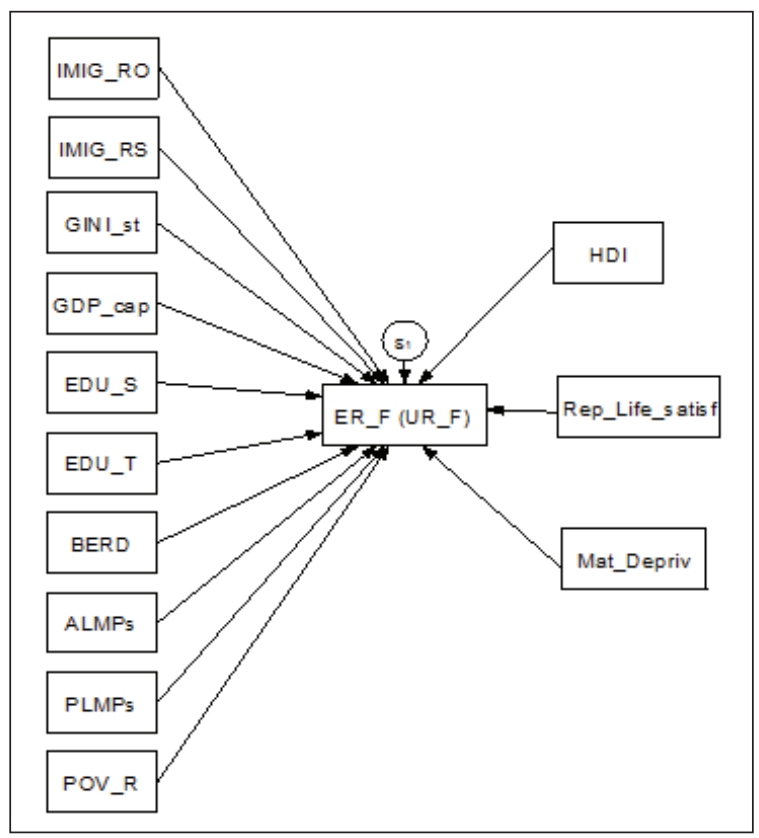

Source: Authors' design

SEM model affords an integrated architecture of analysis for the global migration process with total, direct and indirect connections.

\section{Empirical data and analysis}

\subsection{Empirical data}

We've compiled a balanced panel (2000-2016 data history) and considered the total immigration flows, as well as the immigrants coming from Serbia and Romania into EU-10, along with a complex set of indicators. We've separately extracted the cross-section sample for 2016 (EU-10), with data at the level of 2016 for the socio-psychological variables captured from European Quality of Life Survey 2016 (Eurofound).

We selected a large scale of indicators as proxies for the variables of developed models, as follows (Appendix, Table A1):

i) international migration indicators: economic migration as flows of immigrants and foreign population (IMIG_total); immigrants by country of birth/citizenship: Romania (IMIG_RO), and Serbia (IMIG_RS); 
ii) economic activity and labour market specific indicators: Gross Domestic Product per capita in Euro (GDP_cap); employment rate for the foreign population (ER_F); unemployment rate for the foreign population (UR_F); educational level reflected through the educational attainment for upper secondary and post-secondary non-tertiary education (levels 3-4) (EDU_S), and tertiary education (levels 5-8) (EDU_T); expenditures on active labour market policies (ALMPs) and passive labour market policies (PLMPs); at-risk-of-poverty rate (POV_R); Business Enterprise Research and Development expenditures (BERD); GINI coefficients;

iii) socio-psychological variables: "Participation in society and community: 1. Attendance at religious services apart from weddings, funerals, christenings at least once a week (Att_relig_serv); 2. Attended a meeting of a trade union, political party or action group in last 12 months (Att_meet_political); 3 . Volunteering: educational, cultural, sports or professional associations (Voluntar educ); Security and safety: 4. How likely is that you might lose your job in the next 6 months (Job_sec); Social exclusion and support: 5 . I feel left out of society (Soc_exclus); 6. Some people look down on me because of my job situation or income (Job_discredit); Subjective well-being: 7. Satisfaction with the present standard of living (Livingstand_satisf)".

iv) other socio-psychological variables: Human Development Index (HDI), Selfreported Life Satisfaction (Rep_Life_satisf), Material deprivation ("Economic strain" and "Durables" dimensions) (Mat_Depriv).

The main databases used for collecting the data were (Appendix, Table A1): European Commission - Eurostat, International Migration Database - OECD, World Bank World Development Indicators, UNU WIDER - World Income Inequality Database, European Quality of Life Survey (Eurofound), European Social Survey and World Values Survey (Inglehart et al, 2014), Human Development Data - United Nations Development Programme, World Happiness Report 2016 (Helliwell et al., 2016).

The data was afterwards extrapolated until 2019 (except the data extracted from the European Quality of Life Survey 2016, as we can see in Appendix, Table A1) to better capture the Brexit impact upon labour mobility within the EU, and we've further applied the standardization procedure for each variable, to cover for data benchmarking between countries (as described at the methodology section).

Regarding the stock of immigrants (IMIG_total) within EU-10, the most targeted countries in 2016 were Germany and UK, but also France, Spain, and Italy, followed by Sweden and Austria (Figure 2a). Immigrants with Romanian citizenship (IMIG_RO) mostly preferred Germany and the UK (Figure 2b), while those from Serbia (IMIG_RS) opted for Germany and Austria (Figure 2c). We've selected mainly the immigrants with Romanian and Serbian citizenships from a comparative perspective of an EU Member State and an EU candidate country, in order to better grasp the advantages, benefit spillovers and constraints resulting 
from the European economic integration process related to labour mobility. However, in terms of labour market integration of immigrants into EU-10 host countries, we've reported our empirical analysis to the entire foreign population residing into these economies, proxied through ER_F and UR_F.

Figure 2: Immigrants within EU-10 in 2016, total (a), citizenship from Romania (b), respectively from Serbia (c)

(a)

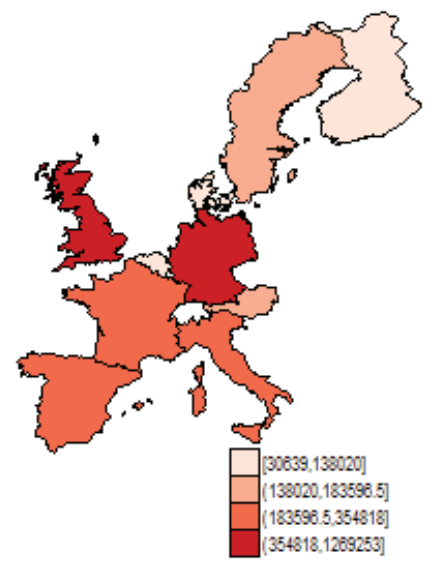

(b)

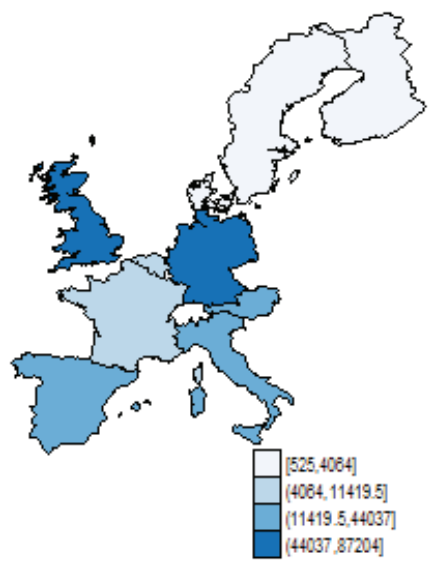

(c)

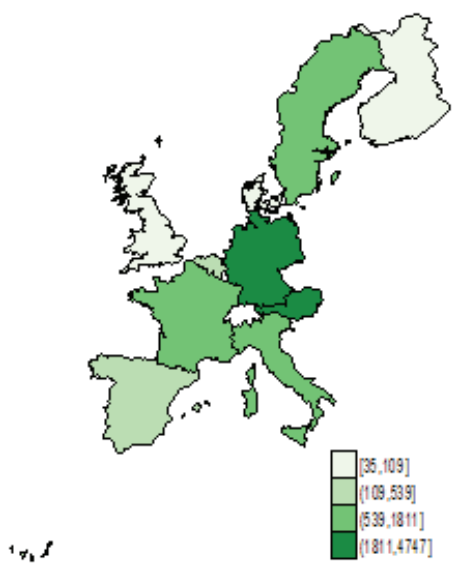

Source: Authors' design, based on OECD (2018)

Socio-psychological credentials are key features for individuals/migrants' wellbeing and their social integration, and thus absolutely necessary and unavoidable to account for in the developed migration strategies, both nationally, and at the European level. In terms of the participation in society and community (Figure 3a), the current European situation highlights that in Italy, Portugal, Ireland, but also in Poland, Slovakia, Croatia, there is an increased participation through the attendance at religious services. If we consider this participation 
through the attendance at meetings of trade unions, political parties or action groups (Figure 3b), most of the Central and Eastern European (CEE) countries, but also Spain, and to some extent Portugal and Belgium, are actively involved in these types of actions.

Figure 3: Participation in society and community, Att_relig_serv (a), and Att_meet_ political (b), Europe, 2016

(a)

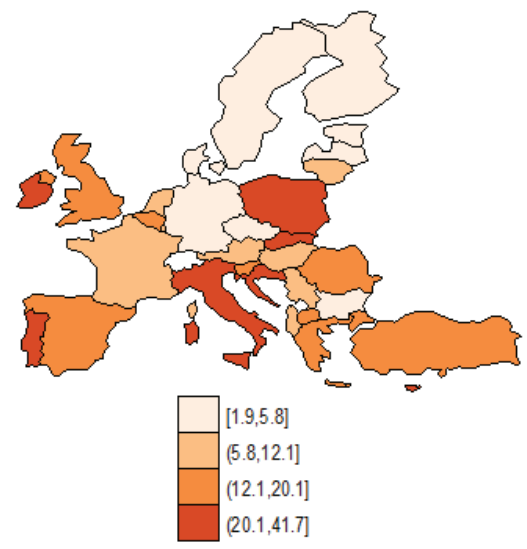

(b)

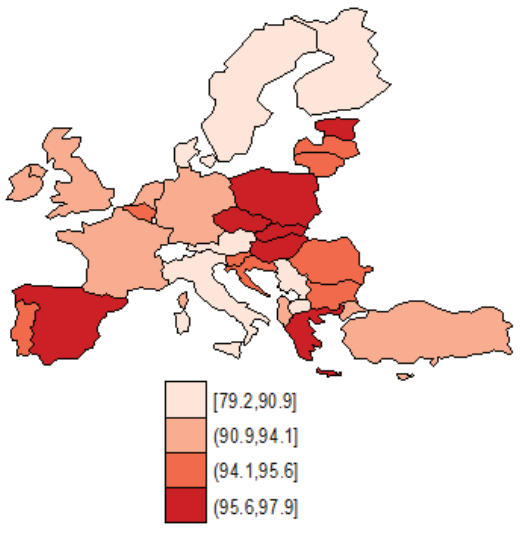

Source: Authors' design, based on Eurofound data - European Quality of Life Survey (2016)

European Quality of Life Survey (2016) reveals that social exclusion (Soc exclus, captured based on the answers to the question „I feel left out of society”) is particularly high for CEE countries, especially in Poland, Hungary, Serbia, Bulgaria, the Baltic States and Romania (Figure 4a). These countries are migrant sending economies, social exclusion being an important determinant of the migration decision. On the other hand, in the case of main migrant receiving economies, such as Germany (in absolute terms), Austria (relative to its population), Denmark, Sweden, Finland, Netherland, but also France, Spain, Italy, the level of social exclusion is very low. These elements are essentials for migrants' integration into host countries.

Individuals' wellbeing, captured through living standard satisfaction (Figure 4b), is at the core of every national and European strategy. Moreover, the living standards expectations at destination are among the decisive factors for the emigration decision. CEE countries, especially Serbia, Bulgaria, Croatia, Latvia have the lowest degree of living standard satisfaction, another key factor in the migration decision for these labour exporting countries, since migrants are seeking for improved living standards at destination, higher wages, better working conditions and, overall, an increased quality of life. 
Figure 4: Social exclusion in 2016 (Soc_exclus) (a), and subjective well-being (livingstand_satisf) (b) in Europe, 2016

(a)

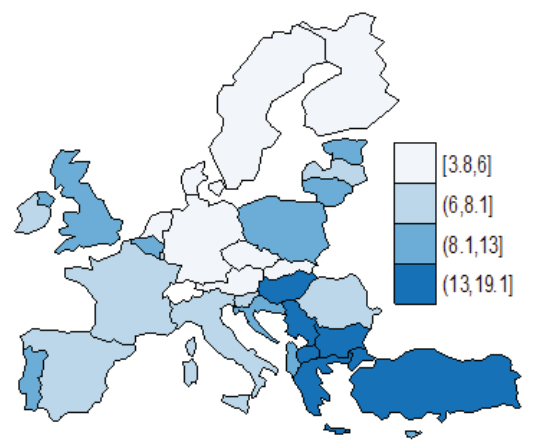

(b)

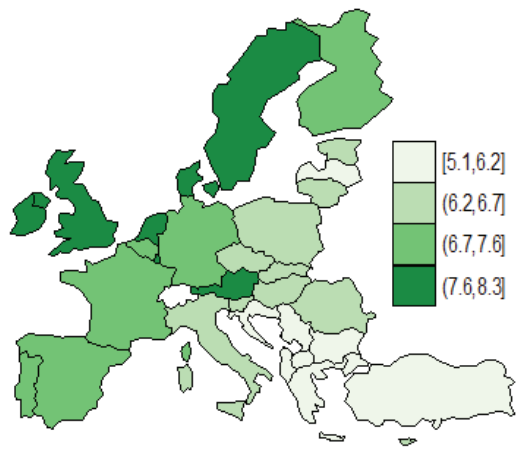

Source: Authors' design, based on Eurofound data - European Quality of Life Survey (2016)

On the other hand, the Nordic countries (particularly Sweden, Denmark and Finland), Austria, Netherlands, the UK, Ireland, but also Germany, France, Spain account for high levels of life satisfaction in general and present living standard satisfaction, being mostly targeted by migrants in general.

\subsection{Spatial analysis results}

In line with the general objective of the research endeavour, we have designed numerous comprehensive macro-econometric models to assess the specific means of positively integrating the immigrants into the EU-10 labour markets (especially immigrants from Romania and Serbia), respectively to increase the employment rate of the foreign population (ER_F), and decrease the unemployment rate (UR_F), used as dependent variables (equation 3), since employment is a key measure of labour market performance.

The independent variables are: GDP_cap, EDU_S, EDU_T, BERD, ALMPs, PLMPs, POV_R, GINI, IMIG_RO and IMIG_RS (Tables 1a, 1b, Appendix, Table A2). For all six estimation models, a particular attention was given to robustness check and validation in order to obtain accurate results (specific tests have been applied and presented at the end of Tables 1a, 1b). Along with the spatial lagautoregressive models (SAR) (models 1 and 2 from the Tables 1a, 1b) and spatial error models (SE) (models 3 and 4 from the Tables 1a, 1b), we've also used robust (RREG) (model 5), and panel corrected standard errors (PCSE) regressions (model 6), to account for endogeneity and heteroscedasticity, thus obtaining consistent and robust estimates (moreover because some findings might be entirely driven by larger economics comprised within the panel e.g. Germany, France). Thus, the most influential points are dropped since the robust regression is based on two 
types of iterations (Huber and Biweight), and resides on the calculation of Cook's distance, applied after running the Ordinary Least Squares (OLS). Detailed results are presented in Tables 1a, 1b, and Table 2 .

Table 1a: Estimation results, additional immigrants from Romania and Serbia in EU-10 most targeted countries (panel) as key explanatory variables, Dependent variable ER_F, 2000-2019

\begin{tabular}{|c|c|c|c|c|c|c|}
\hline \multirow{2}{*}{$\begin{array}{l}\text { Independent } \\
\text { Variables }\end{array}$} & $(1)$ & (2) & (3) & (4) & (5) & (6) \\
\hline & $\begin{array}{c}\text { SAR } \\
\text { (robust) }\end{array}$ & $\begin{array}{c}\text { SAR } \\
\text { (bootstrap) }\end{array}$ & $\begin{array}{c}\mathrm{SE} \\
\text { (robust) }\end{array}$ & $\begin{array}{c}\text { SE } \\
\text { (bootstrap) }\end{array}$ & RREG & PCSE \\
\hline \multirow[t]{2}{*}{ GDP_cap } & $0.128^{* *}$ & 0.128 & $0.119^{*}$ & 0.119 & $0.159^{* *}$ & $0.174^{* * *}$ \\
\hline & $(0.0404)$ & $(0.0743)$ & $(0.0487)$ & $(0.0688)$ & $(0.0566)$ & (0.0499) \\
\hline \multirow[t]{2}{*}{ EDU_S } & 0.120 & 0.120 & 0.0976 & 0.0976 & $0.339^{* * *}$ & $0.183^{*}$ \\
\hline & $(0.0710)$ & $(0.130)$ & (0.0809) & $(0.116)$ & $(0.0930)$ & $(0.0831)$ \\
\hline \multirow[t]{2}{*}{ EDU_T } & 0.00760 & 0.00760 & -0.00276 & -0.00276 & 0.0519 & -0.0150 \\
\hline & $(0.0392)$ & $(0.0707)$ & $(0.0456)$ & $(0.0686)$ & $(0.0619)$ & $(0.0490)$ \\
\hline \multirow[t]{2}{*}{ BERD } & $-0.179^{* *}$ & -0.179 & $-0.225^{* *}$ & $-0.225^{*}$ & $-0.234^{* *}$ & $-0.241^{* * * *}$ \\
\hline & $(0.0590)$ & $(0.107)$ & $(0.0710)$ & $(0.0890)$ & $(0.0882)$ & $(0.0707)$ \\
\hline \multirow[t]{2}{*}{ ALMPs } & 0.0180 & 0.0180 & -0.00652 & -0.00652 & 0.0952 & 0.0659 \\
\hline & $(0.0372)$ & $(0.0729)$ & $(0.0446)$ & $(0.0684)$ & $(0.0647)$ & $(0.0613)$ \\
\hline \multirow[t]{2}{*}{ PLMPs } & $-0.272^{* * *}$ & $-0.272^{* * *}$ & $-0.288^{* * *}$ & $-0.288^{* * *}$ & $-0.456^{* * *}$ & $-0.495^{* * *}$ \\
\hline & $(0.0273)$ & $(0.0427)$ & $(0.0402)$ & $(0.0465)$ & $(0.0614)$ & $(0.0470)$ \\
\hline \multirow[t]{2}{*}{ POV_R } & $-0.292^{* * *}$ & $-0.292^{*}$ & $-0.307^{* * *}$ & $-0.307^{* *}$ & $-0.391^{* * *}$ & $-0.433^{* * *}$ \\
\hline & $(0.0655)$ & $(0.115)$ & $(0.0784)$ & $(0.106)$ & $(0.0940)$ & (0.108) \\
\hline \multirow[t]{2}{*}{ GINI } & $0.232^{* * *}$ & $0.232^{* * *}$ & $0.269^{* * *}$ & $0.269^{* * * *}$ & $0.350^{* * *}$ & $0.318^{* * * *}$ \\
\hline & $(0.0408)$ & $(0.0795)$ & $(0.0569)$ & $(0.0805)$ & $(0.0781)$ & $(0.0775)$ \\
\hline \multirow[t]{2}{*}{ IMIG_RO } & $0.134^{* *}$ & 0.134 & $0.112^{*}$ & 0.112 & $0.193^{* *}$ & $0.176^{* * *}$ \\
\hline & $(0.0413)$ & $(0.0784)$ & $(0.0468)$ & $(0.136)$ & $(0.0642)$ & $(0.0524)$ \\
\hline \multirow[t]{2}{*}{ IMIG_RS } & $-0.146^{* * *}$ & $-0.146^{*}$ & $-0.146^{* *}$ & -0.146 & $-0.174^{* *}$ & $-0.180^{* *}$ \\
\hline & $(0.0346)$ & $(0.0667)$ & $(0.0471)$ & $(0.0804)$ & $(0.0630)$ & $(0.0552)$ \\
\hline \multirow[t]{2}{*}{ _cons } & -0.0335 & -0.0335 & -0.912 & $-0.912^{* * *}$ & -0.0374 & -0.0223 \\
\hline & $(0.0288)$ & $(0.0560)$ & (3.196) & $(0.0528)$ & $(0.0516)$ & (0.0310) \\
\hline \multirow{2}{*}{$\begin{array}{l}\text { rho } \\
\text { cons }\end{array}$} & $0.991^{* * *}$ & $0.991^{* *}$ & & & & \\
\hline & $(0.00898)$ & $(0.359)$ & & & & \\
\hline \multirow{2}{*}{$\begin{array}{l}\text { sigma } \\
\text { cons }\end{array}$} & $0.411^{* * *}$ & $0.411^{* * *}$ & $0.487^{* * *}$ & $0.487^{* * *}$ & & \\
\hline & $(0.0273)$ & $(0.0355)$ & $(0.0282)$ & $(0.0375)$ & & \\
\hline \multirow{2}{*}{$\begin{array}{l}\text { lambda } \\
\text { cons }\end{array}$} & & & $0.989^{* * * *}$ & $0.989^{* *}$ & & \\
\hline & & & $(0.0114)$ & $(0.356)$ & & \\
\hline Test parameters & $\begin{array}{c}\operatorname{chi} 2(10)=357.55 \\
\mathrm{p}=0.000\end{array}$ & $\begin{array}{c}\operatorname{chi} 2(10)=121.71 \\
\mathrm{p}=0.000\end{array}$ & $\begin{array}{c}\operatorname{chi} 2(10)=159.13 \\
\mathrm{p}=0.000\end{array}$ & $\begin{array}{c}\operatorname{chi} 2(10)=138.18 \\
\mathrm{p}=0.000\end{array}$ & $\begin{array}{c}\operatorname{chi} 2(10)=25.68 \\
\mathrm{p}=0.000\end{array}$ & $\begin{array}{c}\operatorname{chi} 2(10)=356.8 \\
\mathrm{p}=0.000\end{array}$ \\
\hline LM & $\begin{array}{r}404.41 \\
(0.000)\end{array}$ & $\begin{array}{r}404.41 \\
(0.000)\end{array}$ & \begin{tabular}{r|}
288.99 \\
$(0.000)$
\end{tabular} & \begin{tabular}{r|}
288.99 \\
$(0.000)$
\end{tabular} & & \\
\hline $\begin{array}{l}\text { Wald test of rho/ } \\
\text { lambda }\end{array}$ & $\begin{array}{r}1.2 \mathrm{e}+04 \\
(0.000)\end{array}$ & $\begin{array}{r}1.2 \mathrm{e}+04 \\
(0.000)\end{array}$ & $\begin{array}{r}7504.6 \\
(0.000)\end{array}$ & $\begin{array}{r}7504.6 \\
(0.000)\end{array}$ & & \\
\hline \multicolumn{7}{|c|}{ Acceptable range for rho: $-2.023<$ rho $<1.000 ;$ Acceptable range for lambda: $-2.023<$ lambda $<1.000$} \\
\hline \multicolumn{7}{|c|}{ Moran's I IMIG_RO I=0.044; $\mathrm{p}=0.000 ;$ IMIG_RS I $=0.123 ; \mathrm{p}=0.000 ; \mathrm{ER}$ F I $=0.397 ; \mathrm{p}=0.000$} \\
\hline$N$ & 200 & 200 & 200 & 200 & 200 & 200 \\
\hline$R^{2}$ & & & & & 0.5761 & 0.5645 \\
\hline
\end{tabular}

Note: Standard errors in parentheses; ${ }^{*} p<0.05,{ }^{* *} p<0.01,{ }^{* * *} p<0.001$; SAR - Spatial lagautoregressive models; SE - Spatial error models; RREG - Robust regression; PCSE - Panel corrected standard errors.

Source: Authors' research 
Grațiela Georgiana Noja et al. • Turning points in migrants'labour market integration...

Zb. rad. Ekon. fak. Rij. $\cdot 2018 \cdot$ vol. $36 \cdot$ no. $2 \cdot 489-518$

LM tests are significant for the entire sample (2000-2019), thus indicating the presence of spatial dependence, while the Moran's I results also reveal a positive global spatial autocorrelation. Therefore, the migrant labour market integration performances achieved by the neighbouring locations are also essential for impacting host economies.

Table 1b: Estimation results, additional immigrants from Romania and Serbia into EU-10 as key explanatory variables, Dependent variable UR_F, 2000-2019

\begin{tabular}{|c|c|c|c|c|c|c|}
\hline \multirow[b]{2}{*}{$\begin{array}{l}\text { Independent } \\
\text { Variables }\end{array}$} & (1) & (2) & (3) & (4) & $(5)$ & (6) \\
\hline & $\begin{array}{c}\text { SAR } \\
\text { (robust) }\end{array}$ & $\begin{array}{c}\text { SAR } \\
\text { (bootstrap) }\end{array}$ & $\begin{array}{c}\mathrm{SE} \\
\text { (robust) }\end{array}$ & $\begin{array}{c}\text { SE } \\
\text { (bootstrap) }\end{array}$ & RREG & PCSE \\
\hline GDP_cap & $\begin{array}{c}-0.174^{* * *} \\
(0.0379)\end{array}$ & $\begin{array}{c}-0.174^{* * *} \\
(0.0448)\end{array}$ & $\begin{array}{c}-0.176^{* * *} \\
(0.0427)\end{array}$ & $\begin{array}{c}-0.176^{* * *} \\
(0.0444)\end{array}$ & $\begin{array}{c}-0.204^{* * *} \\
(0.0468)\end{array}$ & $\begin{array}{l}-0.216^{* * * *} \\
(0.0449)\end{array}$ \\
\hline EDU_S & $\begin{array}{c}-0.445^{* * *} \\
(0.0794)\end{array}$ & $\begin{array}{c}-0.445^{* * *} \\
(0.109)\end{array}$ & $\begin{array}{c}-0.458^{* * *} \\
(0.0834)\end{array}$ & $\begin{array}{c}-0.458^{* * *} \\
(0.108)\end{array}$ & $\begin{array}{c}-0.486^{* * *} \\
(0.0768)\end{array}$ & $\begin{array}{r}-0.480^{* * * *} \\
(0.120)\end{array}$ \\
\hline EDU_T & $\begin{array}{r}-0.0632 \\
(0.0641)\end{array}$ & $\begin{array}{r}-0.0632 \\
(0.0882)\end{array}$ & $\begin{array}{r}-0.0305 \\
(0.0780)\end{array}$ & $\begin{array}{r}-0.0305 \\
(0.0830)\end{array}$ & $\begin{array}{r}0.0749 \\
(0.0511)\end{array}$ & $\begin{array}{l}-0.0419 \\
(0.0566)\end{array}$ \\
\hline BERD & $\begin{array}{l}0.328^{* * *} \\
(0.0771)\end{array}$ & $\begin{array}{l}0.328^{* * *} \\
(0.0929)\end{array}$ & $\begin{array}{l}0.398^{* * *} \\
(0.0818)\end{array}$ & $\begin{array}{l}0.398^{* * *} \\
(0.0899)\end{array}$ & $\begin{array}{l}0.340^{* * *} \\
(0.0728)\end{array}$ & $\begin{array}{l}0.362^{* * *} \\
(0.0720)\end{array}$ \\
\hline ALMPs & $\begin{array}{r}-0.0966 \\
(0.0495)\end{array}$ & $\begin{array}{r}-0.0966 \\
(0.0609)\end{array}$ & $\begin{array}{l}-0.145^{* *} \\
(0.0535)\end{array}$ & $\begin{array}{c}-0.145^{*} \\
(0.0579)\end{array}$ & $\begin{array}{c}-0.120^{*} \\
(0.0535)\end{array}$ & $\begin{array}{r}-0.104 \\
(0.0665)\end{array}$ \\
\hline PLMPs & $\begin{array}{l}0.394^{* * *} \\
(0.0662)\end{array}$ & $\begin{array}{l}0.394^{* * *} \\
(0.0710)\end{array}$ & $\begin{array}{l}0.485^{* * *} \\
(0.0768)\end{array}$ & $\begin{array}{l}0.485^{* * *} \\
(0.0686)\end{array}$ & $\begin{array}{l}0.444^{* * *} \\
(0.0507)\end{array}$ & $\begin{array}{l}0.537^{* * *} \\
(0.0639)\end{array}$ \\
\hline POV_R & $\begin{array}{c}-0.162^{*} \\
(0.0787)\end{array}$ & $\begin{array}{r}-0.162 \\
(0.0933)\end{array}$ & $\begin{array}{r}-0.111 \\
(0.0821)\end{array}$ & $\begin{array}{r}-0.111 \\
(0.100)\end{array}$ & $\begin{array}{r}-0.153 \\
(0.0777)\end{array}$ & $\begin{array}{r}-0.109 \\
(0.0918)\end{array}$ \\
\hline GINI & $\begin{array}{c}0.164^{*} \\
(0.0825)\end{array}$ & $\begin{array}{c}0.164^{*} \\
(0.0826)\end{array}$ & $\begin{array}{r}0.172 \\
(0.0935)\end{array}$ & $\begin{array}{r}0.172^{*} \\
(0.0852)\end{array}$ & $\begin{array}{r}0.0757 \\
(0.0645)\end{array}$ & $\begin{array}{c}0.141^{*} \\
(0.0611)\end{array}$ \\
\hline IMIG_RO & $\begin{array}{r}-0.0721 \\
(0.0573)\end{array}$ & $\begin{array}{r}-0.0721 \\
(0.0915)\end{array}$ & $\begin{array}{r}-0.0464 \\
(0.0626)\end{array}$ & $\begin{array}{r}-0.0464 \\
(0.0643)\end{array}$ & $\begin{array}{r}-0.0167 \\
(0.0530)\end{array}$ & $\begin{array}{l}-0.0833 \\
(0.0577)\end{array}$ \\
\hline IMIG_RS & $\begin{array}{r}-0.0753 \\
(0.0459)\end{array}$ & $\begin{array}{r}-0.0753 \\
(0.0568)\end{array}$ & $\begin{array}{r}-0.0525 \\
(0.0535)\end{array}$ & $\begin{array}{r}-0.0525 \\
(0.0578)\end{array}$ & $\begin{array}{r}-0.0227 \\
(0.0521)\end{array}$ & $\begin{array}{l}-0.0707 \\
(0.0511)\end{array}$ \\
\hline cons & $\begin{array}{r}-0.0235 \\
(0.0371)\end{array}$ & $\begin{array}{r}-0.0235 \\
(0.0551)\end{array}$ & $\begin{array}{r}-0.463 \\
(0.796)\end{array}$ & $\begin{array}{c}-0.463^{* * *} \\
(0.0502)\end{array}$ & $\begin{array}{r}-0.0456 \\
(0.0426) \\
\end{array}$ & $\begin{array}{r}-0.000548 \\
(0.0536)\end{array}$ \\
\hline $\begin{array}{l}\text { rho } \\
\text { cons }\end{array}$ & $\begin{array}{l}0.904^{* * *} \\
(0.0837)\end{array}$ & $\begin{array}{c}0.904^{* * *} \\
(0.256)\end{array}$ & & & & \\
\hline $\begin{array}{l}\text { sigma } \\
\text { cons }\end{array}$ & $\begin{array}{l}0.557^{* * *} \\
(0.0347)\end{array}$ & $\begin{array}{l}0.557^{* * *} \\
(0.0415)\end{array}$ & $\begin{array}{l}0.569^{* * *} \\
(0.0367)\end{array}$ & $\begin{array}{l}0.569^{* * *} \\
(0.0359)\end{array}$ & & \\
\hline $\begin{array}{c}\text { lambda } \\
\text { cons }\end{array}$ & & & $\begin{array}{l}0.939^{* * *} \\
(0.0617) \\
\end{array}$ & $\begin{array}{c}0.939^{*} \\
(0.411) \\
\end{array}$ & & \\
\hline Test parameters & $\begin{array}{c}\operatorname{chi} 2(10)=119.98 \\
\mathrm{p}=0.000\end{array}$ & $\begin{array}{c}\operatorname{chi} 2(10)=161.84 \\
\mathrm{p}=0.000\end{array}$ & $\begin{array}{c}\operatorname{chi} 2(10)=104.91 \\
\mathrm{p}=0.000\end{array}$ & $\begin{array}{c}\operatorname{chi} 2(10)=176.36 \\
\mathrm{p}=0.000\end{array}$ & $\begin{array}{c}\operatorname{chi} 2(10)=32.61 \\
\mathrm{p}=0.000\end{array}$ & $\begin{array}{c}\operatorname{chi} 2(10)=513.04 \\
\mathrm{p}=0.000\end{array}$ \\
\hline LM & $\begin{array}{r}49.79 \\
(0.000) \\
\end{array}$ & $\begin{array}{r}49.79 \\
(0.000) \\
\end{array}$ & $\begin{array}{r}34.91 \\
(0.000) \\
\end{array}$ & $\begin{array}{r}34.91 \\
(0.000) \\
\end{array}$ & & \\
\hline $\begin{array}{l}\text { Wald test of rho/ } \\
\text { lambda }\end{array}$ & $\begin{array}{r}116.58 \\
(0.000)\end{array}$ & \begin{tabular}{r|}
116.58 \\
$(0.000)$
\end{tabular} & $\begin{array}{r}231.74 \\
(0.000)\end{array}$ & $\begin{array}{r}231.74 \\
(0.000)\end{array}$ & & \\
\hline \multicolumn{7}{|c|}{ Acceptable range for rho: $-2.023<$ rho $<1.000$; Acceptable range for lambda: $-2.023<$ lambda $<1.000$} \\
\hline \multicolumn{7}{|c|}{ Moran's I IMIG_RO I=0.044; $\mathrm{p}=0.000 ;$ IMIG_RS I=0.123; $\mathrm{p}=0.000 ;$ UR_F I=0.206; $\mathrm{p}=0.000$} \\
\hline$N$ & 200 & 200 & 200 & 200 & 200 & 200 \\
\hline$R^{2}$ & & & & & 0.633 & 0.607 \\
\hline
\end{tabular}

Note: Standard errors in parentheses; ${ }^{*} p<0.05,{ }^{* *} p<0.01,{ }^{* * *} p<0.001$.

Source: Authors' research 
Rho and lambda are positive and statistically significant for the entire sample (20002019), thus proving positive autoregressive influence of explanatory variables on labour market performance of the foreign population. Wald test results and high values of the $R$-squared are other important measures of model correct specification.

Table 2: Estimation results after introducing socio-psychological variables, Dependent variables: ER_F, UR_F, 2000-2019

\begin{tabular}{|c|c|c|c|c|c|c|c|c|}
\hline \multirow[b]{3}{*}{ Variables } & \multicolumn{4}{|c|}{ Dep. Variable: ER_F } & \multicolumn{4}{|c|}{ Dep. Variable: UR_F } \\
\hline & $(1)$ & $(2)$ & (3) & (4) & $(1)$ & $(2)$ & (3) & (4) \\
\hline & $\begin{array}{c}\text { SAR } \\
\text { (robust) }\end{array}$ & $\begin{array}{c}\mathrm{SE} \\
\text { (robust) }\end{array}$ & RREG & PCSE & $\begin{array}{c}\text { SAR } \\
\text { (robust) }\end{array}$ & $\begin{array}{c}\mathrm{SE} \\
\text { (robust) }\end{array}$ & RREG & PCSE \\
\hline \multirow[t]{2}{*}{ IMIG_RO } & $0.136^{* *}$ & $0.105^{*}$ & $0.205^{* *}$ & $0.189^{* *}$ & -0.0560 & -0.0296 & 0.0595 & -0.0747 \\
\hline & $(0.0444)$ & $(0.0502)$ & $(0.0629)$ & $(0.0634)$ & $(0.0629)$ & $(0.0683)$ & $(0.0474)$ & $(0.0575)$ \\
\hline \multirow[t]{2}{*}{ IMIG_RS } & $-0.170^{* * *}$ & $-0.203^{* *}$ & $-0.207^{* *}$ & $-0.209^{* *}$ & -0.0143 & 0.0254 & -0.00182 & -0.0267 \\
\hline & $(0.0481)$ & $(0.0626)$ & $(0.0717)$ & $(0.0641)$ & $(0.0510)$ & $(0.0593)$ & $(0.0541)$ & $(0.0696)$ \\
\hline \multirow[t]{2}{*}{ GINI } & $0.314^{* * *}$ & $0.301^{* * *}$ & $0.516^{* * *}$ & $0.488^{* * *}$ & 0.0895 & 0.0817 & 0.0141 & -0.00714 \\
\hline & $(0.0541)$ & $(0.0659)$ & $(0.102)$ & $(0.125)$ & $(0.0887)$ & $(0.0906)$ & $(0.0772)$ & $(0.0805)$ \\
\hline \multirow[t]{2}{*}{ HDI } & -4.064 & -4.405 & $-10.64^{* *}$ & $-8.707^{*}$ & 2.925 & 4.487 & -3.176 & 4.430 \\
\hline & $(2.467)$ & $(3.011)$ & $(3.786)$ & $(3.416)$ & $(3.225)$ & $(3.384)$ & $(2.856)$ & $(3.126)$ \\
\hline \multirow[t]{2}{*}{ Rep_life_satisf } & 0.0485 & 0.0589 & -0.0174 & 0.0130 & $-0.210^{* * *}$ & $-0.185^{* *}$ & $-0.370^{* * *}$ & $-0.193^{* * *}$ \\
\hline & $(0.0440)$ & $(0.0568)$ & $(0.0693)$ & $(0.0669)$ & $(0.0517)$ & $(0.0595)$ & $(0.0523)$ & $(0.0541)$ \\
\hline \multirow[t]{2}{*}{ Mat_Depriv } & -0.00852 & 0.113 & -0.0839 & -0.0910 & $-0.121^{*}$ & $-0.162^{*}$ & -0.0678 & -0.0282 \\
\hline & $(0.0491)$ & $(0.0854)$ & $(0.0857)$ & $(0.0910)$ & $(0.0531)$ & $(0.0728)$ & $(0.0646)$ & $(0.0765)$ \\
\hline \multirow[t]{2}{*}{ GDP_cap } & $0.152^{* * *}$ & $0.152^{* *}$ & $0.205^{* * *}$ & $0.212^{* * *}$ & $-0.213^{* * *}$ & $-0.218^{* * *}$ & $-0.227^{* * *}$ & $-0.255^{* * *}$ \\
\hline & $(0.0371)$ & $(0.0473)$ & $(0.0590)$ & $(0.0498)$ & $(0.0385)$ & $(0.0404)$ & $(0.0445)$ & $(0.0352)$ \\
\hline \multirow[t]{2}{*}{ EDU_S } & $0.199^{* *}$ & 0.146 & $0.526^{* * *}$ & $0.368^{* * *}$ & $-0.474^{* * *}$ & $-0.504^{* * *}$ & $-0.415^{* * *}$ & $-0.563^{* * *}$ \\
\hline & $(0.0720)$ & $(0.0868)$ & $(0.111)$ & $(0.0959)$ & $(0.0829)$ & $(0.0843)$ & $(0.0837)$ & $(0.117)$ \\
\hline \multirow[t]{2}{*}{ EDU_T } & 0.0459 & 0.0406 & $0.148^{*}$ & 0.0723 & -0.0809 & -0.0676 & $0.232^{* * *}$ & -0.0733 \\
\hline & $(0.0412)$ & $(0.0504)$ & $(0.0740)$ & $(0.0512)$ & $(0.0852)$ & $(0.0965)$ & $(0.0558)$ & $(0.0522)$ \\
\hline \multirow[t]{2}{*}{ BERD } & $-0.177^{* *}$ & $-0.226^{* *}$ & $-0.170^{*}$ & $-0.236^{* * *}$ & $0.327^{* * *}$ & $0.399^{* * * *}$ & $0.374^{* * *}$ & $0.362^{* * *}$ \\
\hline & $(0.0597)$ & $(0.0716)$ & $(0.0858)$ & $(0.0696)$ & $(0.0731)$ & $(0.0777)$ & $(0.0648)$ & $(0.0753)$ \\
\hline \multirow[t]{2}{*}{ ALMPs } & 0.0305 & 0.00418 & $0.181^{*}$ & 0.121 & -0.0500 & $-0.111^{*}$ & -0.00509 & -0.0713 \\
\hline & $(0.0473)$ & $(0.0621)$ & $(0.0755)$ & $(0.0752)$ & $(0.0560)$ & $(0.0564)$ & $(0.0570)$ & $(0.0653)$ \\
\hline \multirow[t]{2}{*}{ PLMPs } & $-0.257^{* * *}$ & $-0.268^{* * *}$ & $-0.465^{* * *}$ & $-0.486^{* * *}$ & $0.336^{* * *}$ & $0.422^{* * * *}$ & $0.435^{* * *}$ & $0.482^{* * *}$ \\
\hline & $(0.0257)$ & $(0.0410)$ & $(0.0630)$ & $(0.0532)$ & $(0.0610)$ & $(0.0733)$ & $(0.0475)$ & $(0.0595)$ \\
\hline \multirow[t]{2}{*}{ POV_R } & $-0.296^{* * *}$ & $-0.316^{* * *}$ & $-0.328^{* * *}$ & $-0.419^{* * * *}$ & -0.117 & -0.0658 & -0.0731 & -0.0685 \\
\hline & $(0.0674)$ & $(0.0766)$ & $(0.0943)$ & $(0.0889)$ & $(0.0797)$ & $(0.0824)$ & $(0.0712)$ & $(0.0796)$ \\
\hline \multirow[t]{2}{*}{ _cons } & 3.554 & 2.282 & $9.362^{* *}$ & $7.662^{*}$ & -2.611 & -4.203 & 2.755 & -3.911 \\
\hline & $(2.186)$ & (5.058) & (3.346) & $(3.025)$ & $(2.845)$ & (3.211) & $(2.524)$ & $(2.770)$ \\
\hline rho & $0.991^{* * *}$ & & & & $0.924^{* * *}$ & & & \\
\hline _cons & $(0.00908)$ & & & & $(0.0714)$ & & & \\
\hline sigma & $0.404^{* * *}$ & $0.480^{* * *}$ & & & $0.527^{* * *}$ & $0.545^{* * *}$ & & \\
\hline cons & $(0.0273)$ & $(0.0277)$ & & & $(0.0351)$ & $(0.0373)$ & & \\
\hline lambda & & $0.989^{* * *}$ & & & & $0.946^{* * *}$ & & \\
\hline cons & & $(0.0108)$ & & & & $(0.0560)$ & & \\
\hline$N$ & 200 & 200 & 200 & 200 & 200 & 200 & 200 & 200 \\
\hline$R^{2}$ & & & 0.599 & 0.586 & & & 0.761 & 0.637 \\
\hline
\end{tabular}

Note: Standard errors in parentheses; ${ }^{*} p<0.05,{ }^{* *} p<0.01,{ }^{* * *} p<0.001$.

Source: Authors' research 
Grațiela Georgiana Noja et al. • Turning points in migrants'labour market integration...

The highly statistically significant estimated coefficients are slightly different in size, but consistent in sign (have not changed their sign throughout different procedures), except for some socio-psychological variables.

Furthermore, we've introduced three socio-psychological variables related to HDI - Human Development Index, self-reported life satisfaction (Rep_life_satisf), and material deprivation (Mat_Depriv). The results obtained are synthesized in Table 2.

\subsection{Cross-section analysis}

The results of the 2016 cross-section analysis, measured for EU-10 destination countries, comprise: the estimation for the migrants' labour market integration (considering ER_F and UR_F, as dependent variables) (Table 3); and the immigration impacts (total, and separately for Romanian and Serbian immigrants), through socio-psychological aspects (Table 4).

Table 3: Estimation results for EU-10 cross-section 2016, Dependent variables: ER F, UR F

\begin{tabular}{|l|r|r|r|r|}
\hline \multirow{2}{*}{ Independent Variables } & $(1)$ & $(2)$ & $(3)$ & $(4)$ \\
\cline { 2 - 5 } & ER_F_st & ER_F_st & UR_F_st & UR_F_st \\
\hline \multirow{2}{*}{ Att_relig_serv_st } & 0.0336 & & -0.320 & \\
\hline \multirow{2}{*}{ Voluntar_educ_st } & $(0.603)$ & & $(0.348)$ & 0.153 \\
& -0.540 & 0.291 & 0.174 & $(1.153)$ \\
\hline \multirow{2}{*}{ Job_sec_st } & $(0.636)$ & $(1.154)$ & $(0.367)$ & -0.285 \\
& -0.260 & -1.372 & -0.284 & $(1.482)$ \\
\hline \multirow{2}{*}{ Soc_exclus_st } & $(0.638)$ & $(1.484)$ & $(0.368)$ & 0.271 \\
& -0.288 & -0.881 & 0.427 & $(0.995)$ \\
\hline \multirow{2}{*}{ Job_discredit_st } & $(0.856)$ & $(0.996)$ & $(0.494)$ & -0.611 \\
& 0.265 & 0.969 & -0.731 & $(1.146)$ \\
\hline \multirow{2}{*}{ Living_stand_satisf_st } & $(0.928)$ & $(1.147)$ & $(0.535)$ & -1.212 \\
& 1.874 & 3.614 & -1.395 & $(2.351)$ \\
\hline \multirow{2}{*}{ EDU_T_st } & $(1.063)$ & $(2.353)$ & $(0.613)$ & 0.355 \\
& -0.344 & -1.180 & 0.377 & $(1.096)$ \\
\hline \multirow{2}{*}{ ALMPs_st } & $(0.388)$ & $(1.097)$ & $(0.223)$ & 0.554 \\
& -0.618 & -0.757 & 0.457 & $(0.362)$ \\
\hline \multirow{2}{*}{ Att_meet_political_st } & $(0.454)$ & $(0.362)$ & $(0.262)$ & 0.0371 \\
& & 1.673 & & $(2.105)$ \\
\hline \multirow{2}{*}{ cons } & & $(2.107)$ & & -0.209 \\
& & $(1.470$ & -0.233 & $(1.277)$ \\
\hline$R^{2}$ & 0.517 & $0.561)$ & $0.323)$ & 0.928 \\
\hline
\end{tabular}

Note: Standard errors in parentheses; ${ }^{*} p<0.05,{ }^{* *} p<0.01,{ }^{* * *} p<0.001$.

Source: Authors' research 
Furthermore, to account for immigration impacts, through socio-psychological aspects, we've developed other six macro-econometric models (Table 4), focusing both on the total number of immigrants (IMIG_total, models 1 and 2) and immigrants with a particular country of birth/citizenship, respectively Romania (IMIG_RO, models 3 and 4), and Serbia (IMIG_RS, models 5 and 6).

Table 4: Estimation results for EU-10 cross-section 2016 - Shaping factors of the immigration flows through socio-psychological aspects

\begin{tabular}{|c|c|c|c|c|c|c|}
\hline \multirow[b]{2}{*}{ Independent Variables } & (1) & (2) & (3) & (4) & (5) & (6) \\
\hline & $\begin{array}{l}\text { IMIG__ } \\
\text { total_st }\end{array}$ & $\begin{array}{l}\text { IMIG__ } \\
\text { total_st }\end{array}$ & $\begin{array}{l}\text { IMIG__ } \\
\text { RO_st }\end{array}$ & IMIG_RO & $\begin{array}{l}\text { IMIG_ } \\
\text { RS_st }\end{array}$ & IMIG_RS \\
\hline Att_relig_serv_st & $\begin{array}{r}-0.967 \\
(1.343) \\
\end{array}$ & & $\begin{array}{r}-0.0554 \\
(0.176) \\
\end{array}$ & & $\begin{array}{r}0.361 \\
(0.0784) \\
\end{array}$ & \\
\hline Att_meet_political_st & & $\begin{array}{r}7.191 \\
(1.608) \\
\end{array}$ & & $\begin{array}{r}0.705 \\
(0.422) \\
\end{array}$ & & $\begin{array}{r}-0.970 \\
(1.329) \\
\end{array}$ \\
\hline Voluntar_educ_st & $\begin{array}{r}-0.349 \\
(1.415)\end{array}$ & $\begin{array}{r}3.088 \\
(0.880)\end{array}$ & $\begin{array}{r}-0.124 \\
(0.186)\end{array}$ & $\begin{array}{r}0.218 \\
(0.231) \\
\end{array}$ & $\begin{array}{r}0.0314 \\
(0.0826) \\
\end{array}$ & $\begin{array}{r}-0.404 \\
(0.728)\end{array}$ \\
\hline Job_sec_st & $\begin{array}{r}0.255 \\
(1.420) \\
\end{array}$ & $\begin{array}{r}-4.443 \\
(1.132) \\
\end{array}$ & $\begin{array}{l}0.0563 \\
(0.186) \\
\end{array}$ & $\begin{array}{r}-0.407 \\
(0.297) \\
\end{array}$ & $\begin{array}{r}0.0826 \\
(0.0829) \\
\end{array}$ & $\begin{array}{r}0.535 \\
(0.936) \\
\end{array}$ \\
\hline Soc_exclus_st & $\begin{array}{r}0.00506 \\
(1.905) \\
\end{array}$ & $\begin{array}{r}-3.040 \\
(0.760) \\
\end{array}$ & $\begin{array}{r}0.0142 \\
(0.250) \\
\end{array}$ & $\begin{array}{r}-0.267 \\
(0.200) \\
\end{array}$ & $\begin{array}{r}-0.286 \\
(0.111) \\
\end{array}$ & $\begin{array}{r}0.228 \\
(0.628) \\
\end{array}$ \\
\hline Job_discredit_st & $\begin{array}{l}-0.0200 \\
(2.065) \\
\end{array}$ & $\begin{array}{r}3.365 \\
(0.875) \\
\end{array}$ & $\begin{array}{r}-0.0389 \\
(0.271) \\
\end{array}$ & $\begin{array}{r}0.280 \\
(0.230) \\
\end{array}$ & $\begin{array}{r}0.286 \\
(0.121) \\
\end{array}$ & $\begin{array}{r}-0.246 \\
(0.724) \\
\end{array}$ \\
\hline Livingstand_satisf_st & $\begin{array}{r}0.421 \\
(2.366)\end{array}$ & $\begin{array}{r}8.399 \\
(1.796)\end{array}$ & $\begin{array}{r}0.169 \\
(0.310) \\
\end{array}$ & $\begin{array}{r}0.933 \\
(0.471) \\
\end{array}$ & $\begin{array}{r}0.186 \\
(0.138) \\
\end{array}$ & $\begin{array}{r}-0.993 \\
(1.484)\end{array}$ \\
\hline EDU_T_st & $\begin{array}{r}-0.459 \\
(0.862) \\
\end{array}$ & $\begin{array}{r}-4.064 \\
(0.837) \\
\end{array}$ & $\begin{array}{r}-0.124 \\
(0.113) \\
\end{array}$ & $\begin{array}{r}-0.477 \\
(0.220) \\
\end{array}$ & $\begin{array}{r}0.193 \\
(0.0504) \\
\end{array}$ & $\begin{array}{r}0.682 \\
(0.692) \\
\end{array}$ \\
\hline ALMPs_st & $\begin{array}{r}-1.139 \\
(1.009) \\
\end{array}$ & $\begin{array}{l}-1.391 \\
(0.276) \\
\end{array}$ & $\begin{array}{r}-0.204 \\
(0.132) \\
\end{array}$ & $\begin{array}{r}-0.241 \\
(0.0725) \\
\end{array}$ & $\begin{array}{r}0.0271 \\
(0.0589)\end{array}$ & $\begin{array}{l}-0.0104 \\
(0.228)\end{array}$ \\
\hline _cons & $\begin{array}{r}0.857 \\
(1.248)\end{array}$ & $\begin{array}{r}4.963 \\
(0.976) \\
\end{array}$ & $\begin{array}{r}0.0292 \\
(0.164)\end{array}$ & $\begin{array}{r}0.431 \\
(0.256) \\
\end{array}$ & $\begin{array}{r}-0.525 \\
(0.0728)\end{array}$ & $\begin{array}{l}-1.082 \\
(0.807)\end{array}$ \\
\hline$R^{2}$ & 0.747 & 0.982 & 0.895 & 0.969 & 0.984 & 0.766 \\
\hline
\end{tabular}

Note: Standard errors in parentheses; ${ }^{*} p<0.05,{ }^{* *} p<0.01,{ }^{* * *} p<0.001$.

Source: Authors' research. 


\subsection{SEM models}

Finally, we have developed an integrative estimation on the 2000-2019 timespan compiled through SEM models, before (Figure 5, left), and after introducing socio-psychological variables (HDI, self-reported life satisfaction, and material deprivation) (Figure 5, right).

Figure 5: SEM Models - Estimation results before (left) and after (right) introducing socio-psychological variables, 2000-2019
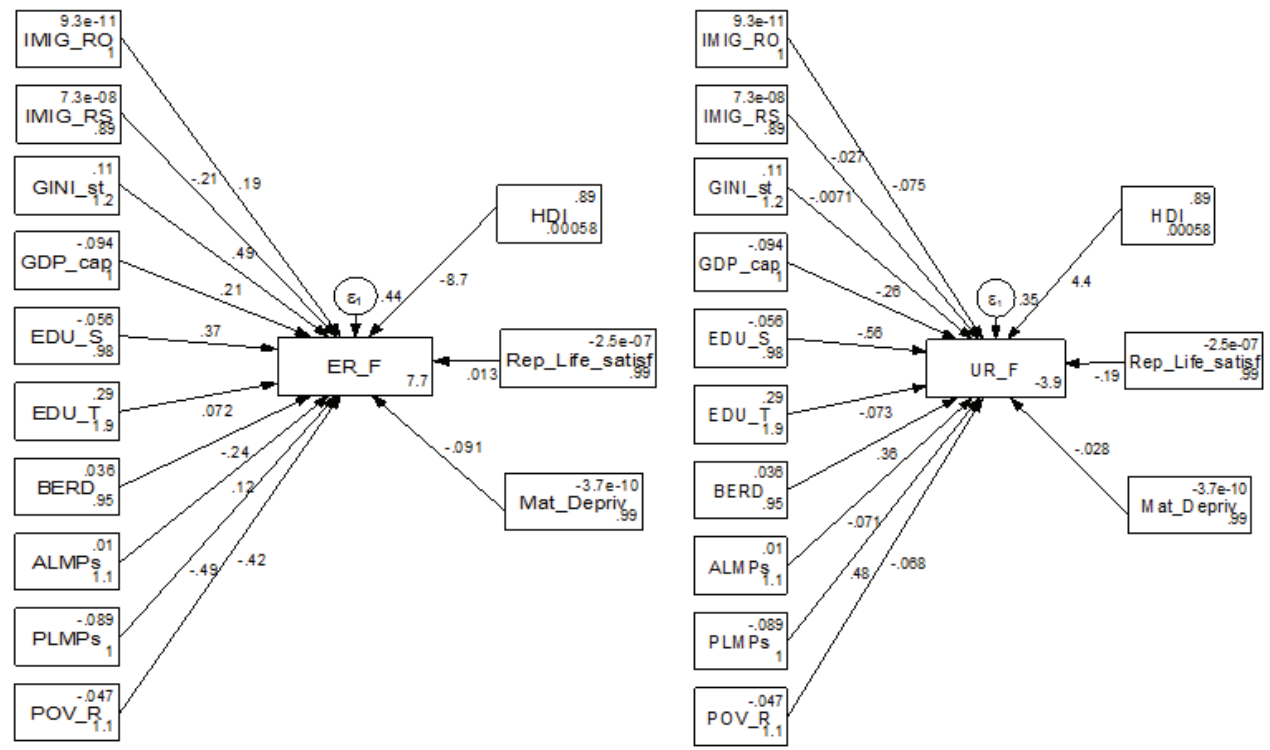

Source: Authors' research

\section{Results and discussion}

\subsection{Spatial analysis}

Based on our results, it can be stated that significant positive consequences reflected through an increase inof the employment rate of foreign population (ER_F) (Table 1a) and, respectively, a downsize in UR_F (Table 1b), are generated by the active labour market policies (ALMPs), and particularly through an improvement in the educational background towards upper-secondary (EDU_S), along with welfare (GDP_cap) increases. The migration specific measures should therefore focus on comprehensive active labour market and educational policies that have proved to be in the benefit of migrants' integration. On the other hand, the PLMPS, namely the unemployment benefits and the early retirement schemes, have a negative impact upon $E R \_F$, acting 
as a disincentive for labour market participation (as reflected through significant decreases in the ER_F/upward in UR_F). Also, contrary to the expectations, the business enterprise $\mathrm{RD}$ expenditures (BERD) increases, determine lower ER_F/ upward UR_F in the EU-10 host countries, thus enforcing the migrant selection process. At the same time, our results show that immigrants from Romania (IMIG RO) tend to be better integrated than those from Serbia (IMIG_RS), mainly due to European membership facilities. In this respect, it should be noted that Romanian immigrants have a higher degree of adaptability to the labor market conditions in host countries because they exhibit higher degrees of cultural similarity. Moreover, the fact that Serbia is not an EU Member State confines Serbian immigrants' integration into EU-10 host countries. These results are in line with Igarashi (2019: 90-91), which specified that "immigrants from non-EU countries, even second-generation immigrants, feel a cultural distance from the host society, whicle the intra-EU immigrants are relatively well-integrated". Thus, $\mathrm{HI}$ is partially fulfilled.

The European Union acknowledges labour mobility as a fundamental pillar of European economic integration and therefore "EU cooperation on the integration of non-EU nationals has developed since the Tampere Programme was adopted back in 1999, while the Common Basic Principles for immigrant integration policy agreed in 2004, provide a strong framework for policy-making in this area" (European Commission, 2018). Hence, EU Member States benefit from important extensive programmes, measures, actions implemented to support immigrants' integration under the Common Agenda for Integration (European Commission, 2005) and the 2016 Action Plan on the integration of Third Country Nationals (European Commission, 2016), along with additional funding through the Asylum, Migration and Integration Fund (where 20\% is allocated to integration).

Material deprivation (Mat_Depriv) reduces the employment opportunities of foreign population and their labour market integration, while human development index (HDI) also has a negative impact. Nevertheless, the educational programmes deployed in EU-10 destination countries are essential for labour market integration, both EDU_S and EDU_T having positive estimated coefficients and an increased level of statistical significance (particularly EDU_S, mostly at $0.1 \%$ level).

HDI represents an important measure for assessing the economic development of a country through its citizens, their skills and capabilities, and comprises three key dimensions of human development: ,a long and healthy life, being knowledgeable and have a decent standard of living" (UNDP, 2016). Thus, its negative estimated coefficient in the developed macroeconometric models might point out that these important human development dimensions aren't granted for immigrants or achieved by them into EU-10 host economies, thus inducing an adverse impact on their labour market integration (captured through a reduction in ER_F). Nevertheless, when an increased life satisfaction (Rep_Life_satisf) is achieved within these migrant receiving economies by immigrants from Romania and 
Serbia, positive effects are generated upon their integration as well. However, on these lines, and as before introducing socio-psychological variables, the differences in terms of labour market integration of Romanian and Serbian immigrants are repeatedly revealed through increased ER_F for Romanian immigrants, and lower ER_F for immigrants coming from Serbia. Thus, $\mathrm{H} 2$ is also partially fulfilled.

\subsection{Cross section analysis}

The results of the 2016 cross-section analysis on migrants' labour market integration, after introducing other socio-psychological variables (Table 3, Appendix, Table A3), revealed positive credentials, reflected through an increased participation in society and community, mainly the population attitudes towards religion (Att_relig_serv) (models 1 and 3), as well as attendance to a meeting of a trade union, political party or action group in last 12 months (Att_meet_political) (models 2 and 4). At the same time, increased living standards satisfaction (Living stand_satisf) also positively reverberates on migrant integration into host economies since it tends to increase the ER_F, respectively to decrease the UR_F.

However, negative effects are generated by social exclusion and reduced job security (Job_sec). The risk of job loss is extremely high for migrants since they are mainly occupying jobs involving routine tasks that could be covered by machines as automation progresses. Moreover, volunteering to educational, cultural, sports or professional associations (Voluntar_educ) acts like a disincentive and rather induces a decrease in active labour market participation. Thus, H3 is fulfilled.

The results of the 2016 cross-section analysis on the immigration impacts, through socio-psychological aspects, revealed that, overall, the total immigration flows (models 1 and 2) are mainly shaped by the expectations related to the living standards at destination (Livingstand_satisf), job opportunities (Job_sec), and a positive social environment (Soc_exclus), without discrimination and labour market distortions. Still, the estimated coefficients have a lower degree of statistical significance. On these lines, Björnsson et al., (2018: 830) also state that "discrimination is one other such aspect that decreases the individual's possibility to move to where job opportunities are greater", grasping that immigrants live further from job opportunities than natives.

When we've considered separately the EU-10 immigrants coming from Romania (models 3 and 4) and Serbia (models 5 and 6), we've noticed that the Romanian migrants are mainly attracted by political stability in terms of the migration policies enforced by the destination countries that are continuously open to receive immigrants (Att_meet_political), increased job security (Job_sec), positive social environment (Soc_Exclus), and the expectations related to the living standards at destination (Livingstand_satisf), while Serbian migrants are rather attracted by the social environment at destination, namely host population's attitude towards 
religion (Att_relig_serv), volunteering and educational activities (Voluntar_educ), as well as accurate ALMPs oriented towards lifelong learning and job creation. In terms of labour market integration, both Serbian and especially Romanian migrants contribute to a significant reduction in the unemployment rate of the foreign population, thus reflecting that they tend to positively integrate into the host economies/labour markets/societies.

\subsection{SEM results}

SEM results before introducing socio-psychological variables (Figure 5, left) highlight positive and statistically significant effects upon ER_F, obtained in case of increased immigrants from Romania (IMIG_RO), along with welfare (GDP_cap) increases, and improvement in the educational background towards upper-secondary (EDU_S). These effects are emphasized after considering socio-psychological variables (HDI, self-reported life satisfaction, and material deprivation), along with migration and labour market variables (Figure 5, right).

On the other side, negatively and statistically significant effects upon EU-10 labour markets are revealed by the same variables as in case of previous spatial spillovers results, namely increasing immigrants from Serbia (IMIG_RS), BERD, the unemployment benefits and early retirement schemes (PLMPs), as reflected through significant decreases in ER_F, and an upward in UR_F (Figure 5, left). In case of socio-psychological variables (Figure 5, right), an increased life satisfaction (Rep_Life_satisf) improves migrants's ${ }^{6}$ labour market participation, captured through ER_F upturn, and a reduction of UR_F. Material deprivation (Mat_Depriv) reduces the employment opportunities of foreign population and their labour market integration, while human development index (HDI) also has a negative impact. $\mathrm{HI}$ and $\mathrm{H} 2$ are partially fulfilled.

\section{Concluding remarks}

This study pursued several methods to detect, on one hand, specific ways for migrants' labour market integration into receiving economies (EU-10, most targeted countries by migrants), with positive results reflected through an increase in the employment rates (decrease in the unemployment rate) of the foreign population, and, on the other hand, to capture the importance of economic and socio-psychological variables in this process.

The models were developed for two dependent variables (employment and unemployment rates of the foreign population - as key measures of migrants' labour market performance/integration), considering two scenarios: before and after introducing socio-psychological variables. In compliance with our general research 
objective, we have defined three research hypotheses, tested and verified through the methodological endeavour.

In case of spatial spillovers and SEM, the results obtained reveal similar consequences, respectively significant positive effects reflected through an increase in the employment rate of the foreign population, which are generated by the active labour market policies, along with an improvement in the educational background, especially towards secondary education, GDP per capita increases, while immigrants are partially integrated into host countries' labour markets (more facilities for the Romanian than the Serbian migrants in the context of European integration). Thus H1 is partially fulfilled. When we've introduced the sociopsychological variables, we've noticed that positive credentials on migrants' integration are reflected through an increase of life satisfaction. These results are in line with the work depoyed by Kogan et al. (2018: 1783), which also stated that „immigrants are likely to be more satisfied in countries that offer more welcoming social settings". Material deprivation has adverse effects on the labour market integration of foreign population by reducing their employment opportunities, while human development index also has a negative impact. Again $\mathrm{H} 2$ is partially fulfilled, since HDI does not support the immigration process.

The results of cross-sectional analysis for 2016 revealed that an increased participation in society and community and living standards satisfaction positively reverberate on migrant integration into EU-10 host economies. However, negative effects are induced by social exclusion and reduced job security/increased fear, possibility, to lose the job in the near future. H3 is thus fulfilled. By considering the EU-10 immigrants coming from Romania and Serbia, we've noticed that the two migrant categories are attracted mainly by political stability in terms of the migration policies enforced by the destination countries, increased job security, a positive social environment at destination, as well as accurate ALMPs oriented towards lifelong learning and job creation.

The strategies, policies and specific measures implemented to properly integrate the immigrants into host countries' labour markets are a core interest for policy makers, aiming to decrease or even dismantle the potential negative effects and to emphasize the positive credentials induced by the international migration. National and local authorities are strongly engaged in migrants' integration process, having competences in designing specific policies with the support of the European institutions. The actions of general public institutions (e.g. the education system or the institutional labor market arrangements in host countries) and the specific institutions to different immigrant groups (e.g. religious or cultural establishments) can facilitate, restrict or even exclude access or outcome for immigrants. By entailing the research endeavour, these authorities could benefit from the results obtained by implementing educational programmes for immigrants, including migrant children (language assessment and learning courses, inclusive, upskilling, 
employment and vocational training), provide migrants' access to healthcare and basic services, by paying a particular attention to the socio-psychological balance and wellbeing of migrants and their families. Furthermore, based on the research results, decision makers should consider various ways to improve employment conditions, mainly through accurate and tailored ALMPs, that have proven to induce positive credentials for labour market integration of immigrants. A reconsideration of PLMPs should also be accounted by policy makers since the preliminary results have shown that unemployment benefits act as a disincentive for immigrants to become actively integrated into the labour market. The migration specific measures should also focus on comprehensive educational policies, since initial estimations show that an increase in the educational level for the low-skilled workers (towards upper-secondary) induces a decrease in unemployment rates for the foreign population. Nevertheless, the socio-psychological aspects are essentials for migrants' wellbeing and integration, with positive spillovers upon the general welfare of the society and are therefore extremely important to consider.

Our research is not without limitations mainly induced by low data availability for longer time series that are accurate in revealing the amplitude of the migration phenomenon and the importance of socio-psychological credentials. Thus, we aim to complete the sample with immigrants coming from other countries (e.g. Bulgaria, Poland, Hungary, Croatia) for the years 2014-2016. Furthermore, we intend to expand the immigration analysis to a bilateral matrix approach following the emigration-immigration-return migration axis, with a particular interest on migration for family reunification.

\section{References}

Barbu, T.C, Boitan, A.I. (2018) "Immigrants' Impact on Financial Market European Countries' Evidence", Zbornik Radova Ekonomskog Fakulteta u Rijeci: Časopis za Ekonomsku Teoriju i Praksu, Vol. 36, No. 1, pp. 183-212, doi: 10.18045/zbefri.2018.1.183.

Berry, J.W. (1997) "Immigration, Acculturation and Adaptation", Applied Psychology: An International Review, Vol. 46, No. 1, pp. 5-34, doi: 10.1111/j.1464-0597.1997. tb01087.x.

Betz, W, Simpson, N.B. (2013) "The Effects of International Migration on the WellBeing of Native Populations in Europe", Journal of Migration, Vol. 2, No. 12, doi: 10.1186/2193-9039-2-12.

Björnsson, D.F., Kopsch, F., Zoega, G. (2018) "Discrimination in the Housing Market as an Impediment to European Labour Force Integration: the Case of Iceland", International Migration \& Integration, Vol. 19, No. 3, pp. 829-847, doi: 10.1007/s12134-018-0574-0. 
Borjas, G.J. (2000) "Foreign-Born Teaching Assistants and the Academic Performance of Undergraduates", American Economic Review, Vol, 90, No. 2, pp. 355-359, doi: 10.1257/aer.90.2.355.

Brickman, P., Campbell, D. (1971) "Hedonic Relativism and Planning the Good Society". In Apley, M.H. ed., Adaptation Level Theory: A Symposium, New York: Academic Press.

Chiswick, B., Miller, P.W. (2014) Handbook of the Economics of International Migration: The Impact, Oxford: Elsevier.

Efron, B., Tibshirani, R.G. (1993) An Introduction to the Bootstrap, Boca Raton: Chapman \& Hall/CRC, doi: 10.1007/978-1-4899-4541-9.

European Commission (2005) A Common Agenda for Integration - Framework for the Integration of Third-Country Nationals in the European Union, Brussels: $\operatorname{COM}(2005) 389$.

European Commission (2016) Action Plan on the Integration of Third-Country Nationals, Brussels: COM(2016) 377.

European Commission (2018) Eurostat Database.

European Foundation for the Improvement of Living and Working Conditions (Eurofound) (2018) European Quality of Life Survey 2016.

European Research Infrastructure Consortium (ESS-ERIC) (2016) European Social Survey.

Fong, E., Guo, H. (2018) "Immigrant integration and their negative sentiments toward recent immigrants: The case of Hong Kong", Asian and Pacific Migration Journal, Vol. 27, No. 2, pp. 166-189, doi: 10.1177/0117196818772326.

Glass, A.J., Kenjegalieva, K, Sickles, R. (2012) "The Economic Case for the Spatial Error Model with an Application to State Vehicle Usage in the U.S.", Rice University manuscris [Internet]. pp. 1-31. Available at: <https://pdfs. semanticscholar.org/40ff/8 eeaae7f1326813e500253adc3eaff0490a9.pdf> [Accessed: August 3, 2018].

Goldner, S.C., Epstein, G.S. (2014) "Age at Immigration and High School Dropouts”, IZA Journal of Migration, Vol. 3, No. 1, p. 19, doi: 10.1186/s40176014-0019-2.

Helliwell, J., Layard, R., Sachs, J. (2016) World Happiness Report 2016, Update (Vol. I), New York: Sustainable Development Solutions Network.

Huber, P. (2015) “What Institutions Help Immigrants Integrate?”, WWWforEurope Working Paper, No. 77, Vienna, doi: 10.2139/ssrn.2565064.

Igarashi, A. (2019) "Till multiculturalism do us part: Multicultural policies and the National Identification of Immigrants in European Countries", Social Science Research, Vol. 77, pp. 88-100, doi: 10.1016/j.ssresearch.2018.10.005.

Inglehart, R.C. et al. (eds.). (2014) "World Values Survey: All Rounds - CountryPooled Datafile", Madrid: JD Systems Institute [Internet]. Available at: <http:// 
www.worldvaluessurvey.org/WVSDocumentationWVL.jsp> [Accessed: June 4, 2018].

Kahneman, D. (2002) "Maps of Bounded Rationality: A Perspective on Intuitive Judgment and Choice", Nobel Prize Lecture, No. 8, pp. 351-401.

Kahneman, D., Tversky, A. (1979) "Prospect theory", Econometrica, Vol. 47, No. 2, pp. 263-292, doi: 10.2307/1914185.

Knies, G., Nandi, A., Platt, L. (2016) "Life satisfaction, ethnicity and neighbourhoods: Is there an effect of neighbourhood ethnic composition on life satisfaction?", Social Science Research, Vol. 60, pp. 110-124, doi: 10.1016/j. ssresearch.2016.01.010.

Kogan, I., Shen, J., Siegert, M. (2018) "What Makes a Satisfied Immigrant? HostCountry Characteristics and Immigrants' Life Satisfaction in Eighteen European Countries", Journal of Happiness Studies, Vol. 19, No. 6, pp. 1783-1809, doi: 10.1007/s10902-017-9896-4.

Milanovic, B. (2010) The Haves and the Have-Nots. A Brief and Idiosyncratic History of Global Inequality, New York: Basic Books.

OECD (2005) Handbook on Constructing Composite Indicators: Methodology and Userguide, Statistics Working Paper, Paris: OECD, doi: 10.1787/9789264043466en.

OECD (2018) International Migration Outlook, Paris: OECD, doi: 10.1787/migr outlook-2018-en.

Otrachshenko, V., Popova, O. (2014) "Life (dis)satisfaction and the intention to migrate: Evidence from Central and Eastern Europe", The Journal of SocioEconomics, Vol. 48, pp. 40-49, doi: 10.1016/j.socec.2013.09.008.

Strijbis, O., Polavieja, J. (2018) "Immigrants against immigration: Competition, identity and immigrants' vote on free movement in Switzerland", Electoral Studies, Vol. 56, pp. 150-157, doi: 10.1016/j.electstud.2018.10.001.

United Nations Development Programme (UNDP) Human Development Data (1990-2015).

UNU WIDER (2018) World Income Inequality Database, Helsinki: United Nations University.

Van Praag, B.M.S. (1971) "The Welfare Function of Income in Belgium: An Empirical Investigation”, European Economic Review, Vol. 4, No. 3, pp. 33-62, doi: 10.1016/0014-2921(71)90045-6.

Viton, P. (2010) "Notes on Spatial Econometric Models", City and Regional Planning, Vol. 870, No. 3, pp. 1-23.

Voicu, B., Vlase, I. (2014) "High-skilled immigrants in times of crisis. A crossEuropean analysis", International Journal of Intercultural Relations, Vol. 42, pp. 25-37, doi: 10.1016/j.ijintrel.2014.07.003. 
Walker, I., Pettigrew, T.F. (1984) "Relative Deprivation Theory. An Overview and Conceptual Critique", British Journal of Social Psychology, Vol. 23, No. 4, pp. 301-310, doi: 10.1111/j.2044-8309.1984.tb00645.x.

Walkowitz, G. (2019) "Employers Discriminate against Immigrants and Criminal Offenders - Experimental Evidence", Economics Letters, Vol. 174, doi: 10.1016/ j.econlet.2018.11.003.

World Bank (2018) World Development Indicators. 


\title{
Točke preokreta $u$ integraciji migranata na tržište rada u Europi i prelijevanje koristi u Rumunjsku i Srbiju: uloga socio-psiholoških vjerodajnica ${ }^{1}$
}

\author{
Grațiela Georgiana Noja ${ }^{2}$, Nebojša Petrovic $^{3}$, Mirela Cristea ${ }^{4}$
}

\begin{abstract}
Sažetak
U ovom radu primjenjuje se dvostruka analiza koja obuhvaća ekonomske i sociopsihološke koordinate $u$ integraciji migranata na tržišta rada $u$ deset zemalja EU-a (EU-10), uglavnom imigrantima (naime: Belgija, Danska, Finska, Francuska, Velika Britanija, Njemačka, Austrija, Švedska, Italija i Španjolska). Fokus je na otkrivanju važnosti socio-psiholoških vjerodajnica za aktivno sudjelovanje imigranata na tržištu rada s ciljem ekstrapolacije čimbenika (razdoblje od 2000-2019), koji mogu potaknuti ili zakomplicirati sličan proces u budućnosti. Osim ukupnih tijekova useljavanja, osobita pozornost u istraživanju je stavljena prelijevanje koristi na dobitke za Srbiju i Rumunjsku u njihovim migracijskim izazovima prema EU-10. Skup metoda i makro-ekonometrijskih modela, temeljenih na prostornoj analizi, analizi poprečnog presjeka i modeliranju strukturalnih jednadžbi, primjenjuje se na uravnoteženom panelu podataka zemalja koji je formirala EU-10. Rezultati naglašavaju da se povećano sudjelovanje u društvu, zajednici i poboljšanje zadovoljstva životnim standardom (subjektivno blagostanje) pozitivno odražava na integraciju migranata u gospodarstva domaćina, budući da dovodi do tendencije povećanja stope zaposlenosti stranog stanovništva. Suprotno tome, negativan utjecaj nastaje uslijed socijalne isključenosti i smanjene sigurnosti radnih mjesta, dok materijalno lišavanje također značajno smanjuje mogućnosti zapošljavanja stranog stanovništva i njihovu aktivnu integraciju na tržište rada.
\end{abstract}

Ključne riječi: imigranti, integracija tržišta rada, nezaposlenost, europske strategije, makro-ekonometrijsko modeliranje

JEL klasifikacija: F22, F63, H19, J21, J24

1 Dio ovog rada proveden je u okviru STSM (Short-Term Scientific Mission) - kratkoročne znanstvene misije, COST Action CA16111 "Međunarodna mreža podataka za istraživanje etničkih i imigrantskih manjina" (ETHMIGSURVEYDATA). Zahvaljujemo recenzentima na njihovim primjedbama koje su iznimno korisne u oblikovanju cjelokupnog istraživanja.

${ }^{2}$ Izvanredni profesor, West University of Timisoara, Faculty of Economics and Business Administration, East European Center for Research in Economics and Business, 16 Pestalozzi Street, 300115 Temišvar, Rumunjska. Znanstveni interes: ekonomija rada, globalizacija $i$ regionalna ekonomska integracija, međunarodna migracija, ekonometrijsko modeliranje. Tel.: +40744764002. E-mail: gratiela.noja@e-uvt.ro.Web stranica: https://feaa.uvt.ro/ro/veziprofil-utilizator/gratiela.carica. (corresponding author).

3 Redoviti profesor, Univerzitet u Beogradu, Filozofski fakultet, Čika-Ljubina 18-20, 11000 Beograd, Srbija. Znanstvena pripadnost: pomirba/usklađivanje, društvena pitanja, migracije, mirovne studije, nejednakosti.Tel.: +381113206166. E-mail: npetrovi@f.bg.ac.rs. Web stranica: https:// www.researchgate.net/profile/Nebojsa_Petrovic3. http://www.f.bg.ac.rs/cv/PENE_228b.pdf.

4 Redoviti profesor, University of Craiova, Faculty of Economics and Business Administration, Center for Banking and Financial Research, 13 A I Cuza Street, 200585 Craiova, Rumunjska. Znanstveni interes: makroekonomska istraživanja, osiguranja, mirovinski fondovi. Tel.: +40740-310-520. E-mail: mirelas.cristea@gmail.com. Web stranica: http://feaa.ucv.ro/one/index. php?option=com_contentbuilder\&view $=$ details\&Itemid $=776 \& l a n g=r o$. 


\section{Appendices}

Table A1: Variables used in the empirical research

\begin{tabular}{|c|c|c|c|}
\hline Acronym & Description & Period & Source \\
\hline IMIG_total & $\begin{array}{l}\text { Economic migration as flows and stock of } \\
\text { immigrants and foreign population (number) }\end{array}$ & $2000-2016$ & OECD, Eurostat \\
\hline IMIG_RO & $\begin{array}{l}\text { Immigrants by country of birth/citizenship: Romania } \\
\text { (number) }\end{array}$ & $2000-2016$ & OECD, Eurostat \\
\hline IMIG_RS & $\begin{array}{l}\text { Immigrants by country of birth/citizenship: Serbia } \\
\text { (number) }\end{array}$ & $2000-2016$ & OECD, Eurostat \\
\hline GDP_cap & Gross domestic product per capita (Euro) & $2000-2016$ & UNCTADstat \\
\hline ER_F & Employment rate for the foreign population (\%) & $2000-2016$ & Eurostat, OECD \\
\hline UR_F & Unemployment rate for the foreign population $(\%)$ & $2000-2016$ & Eurostat, OECD \\
\hline EDU_S & $\begin{array}{l}\text { Educational level reflected through the educational } \\
\text { attainment for upper secondary and post-secondary } \\
\text { non-tertiary education (levels } 3-4 \text { ) }\end{array}$ & $2000-2016$ & Eurostat \\
\hline EDU_T & $\begin{array}{l}\text { Educational level reflected through the educational } \\
\text { attainment for tertiary education (levels } 5-8 \text { ) }\end{array}$ & $2000-2016$ & Eurostat \\
\hline ALMPs & $\begin{array}{l}\text { Expenditures on active labor market policies ( } \% \text { of } \\
\text { GDP) }\end{array}$ & $2000-2016$ & Eurostat \\
\hline PLMPs & $\begin{array}{l}\text { Expenditures on passive labor market policies ( } \% \\
\text { of GDP) }\end{array}$ & $2000-2016$ & Eurostat \\
\hline POV_R & At-risk-of-poverty-rate $(\%)$ & $2000-2016$ & Eurostat, World Bank \\
\hline BERD & $\begin{array}{l}\text { Business Enterprise Research and Development } \\
\text { Expenditures (\% of GDP) }\end{array}$ & $2000-2016$ & Eurostat \\
\hline GINI & Gini coefficients (index) & $2000-2016$ & UNU WIDER \\
\hline Att_relig_serv & $\begin{array}{l}\text { Attendance at religious services apart from } \\
\text { weddings, funerals, christenings at least once a week }\end{array}$ & 2016 & $\begin{array}{l}\text { European Quality of } \\
\text { Life Survey }\end{array}$ \\
\hline $\begin{array}{l}\text { Att_meet_- } \\
\text { political }\end{array}$ & $\begin{array}{l}\text { Attended a meeting of a trade union, political party } \\
\text { or action group in last } 12 \text { months }\end{array}$ & 2016 & $\begin{array}{l}\text { European Quality of } \\
\text { Life Survey }\end{array}$ \\
\hline Voluntar_educ & $\begin{array}{l}\text { Volunteering: educational, cultural, sports or } \\
\text { professional associations }\end{array}$ & 2016 & $\begin{array}{l}\text { European Quality of } \\
\text { Life Survey }\end{array}$ \\
\hline Job_sec & $\begin{array}{l}\text { How likely is that you might lose your job in the } \\
\text { next } 6 \text { months }\end{array}$ & 2016 & $\begin{array}{l}\text { European Quality of } \\
\text { Life Survey }\end{array}$ \\
\hline Soc_exclus & I feel left out of society & 2016 & $\begin{array}{l}\text { European Quality of } \\
\text { Life Survey }\end{array}$ \\
\hline Job_discredit & $\begin{array}{l}\text { Some people look down on me because of my job } \\
\text { situation or income }\end{array}$ & 2016 & $\begin{array}{l}\text { European Quality of } \\
\text { Life Survey }\end{array}$ \\
\hline $\begin{array}{l}\text { Livingstand_- } \\
\text { satisf }\end{array}$ & Satisfaction with the present standard of living & 2016 & $\begin{array}{l}\text { European Quality of } \\
\text { Life Survey }\end{array}$ \\
\hline HDI & Human Development Index & $2000-2016$ & $\begin{array}{l}\text { United Nations } \\
\text { Development } \\
\text { Programme, Human } \\
\text { Development Data }\end{array}$ \\
\hline Rep_Life_satisf & Self-reported Life Satisfaction & $2000-2016$ & $\begin{array}{l}\text { World Happiness } \\
\text { Report } 2016\end{array}$ \\
\hline Mat_Depriv & Material deprivation ( $\%$ of population) & $2000-2016$ & $\begin{array}{l}\text { European Social } \\
\text { Survey, World Values } \\
\text { Survey }\end{array}$ \\
\hline
\end{tabular}

\section{Source: Authors's compilation}


Table A2: Summary statistics of the indicators, EU-10, 2000-2019

\begin{tabular}{|c|c|c|c|c|c|}
\hline Variables & $\mathrm{N}$ & Mean & $\begin{array}{l}\text { Standard } \\
\text { deviation }\end{array}$ & Min & Max \\
\hline IMIG_total & 200 & 305259.6 & 308797.9 & 16895 & 1845793 \\
\hline IMIG_RO & 200 & 35785.72 & 89307.18 & -17268 & 657253 \\
\hline IMIG_RS & 200 & 2542.544 & 5358.684 & -8185 & 33758 \\
\hline ER_F & 200 & 61.071 & 5.591304 & 45.2 & 74.4 \\
\hline UR_F & 200 & 13.6625 & 5.508645 & 3.600001 & 35.4 \\
\hline GDP_cap & 200 & 33923.33 & 10840.04 & 8735.141 & 64161.97 \\
\hline POV & 200 & 20.49 & 4.646142 & 9.1 & 30.30001 \\
\hline BERD & 200 & 1.28585 & .5970249 & .38 & 2.985 \\
\hline ALMPs & 200 & .663075 & .3801446 & .035 & 1.973 \\
\hline PLMPs & 200 & 1.342235 & .6662019 & -.0039999 & 3.053 \\
\hline EDU_S & 200 & 42.9665 & 9.902683 & 13.40001 & 60.8 \\
\hline EDU_T & 200 & 26.62 & 8.937471 & 8.1 & 75.89999 \\
\hline GINI & 200 & 28.85 & 3.588049 & 20.6 & 39.7 \\
\hline HDI & 200 & .88589 & .024085 & .825 & .9339999 \\
\hline Mat_Depriv & 200 & 34534.61 & 28150.41 & 5081 & 82836 \\
\hline Rep_life_satisf & 200 & 7.184328 & .6381259 & 5.839314 & 9.646856 \\
\hline
\end{tabular}

Source: Authors' process in Stata

Table A3: Summary statistics EU-10, with socio-psychological variables, 2016

\begin{tabular}{|l|r|r|r|r|r|}
\hline \multicolumn{1}{|c|}{ Variables } & $\mathrm{N}$ & \multicolumn{1}{c|}{ Mean } & \multicolumn{1}{c|}{$\begin{array}{c}\text { Standard } \\
\text { deviation }\end{array}$} & \multicolumn{1}{c|}{ Min } & \multicolumn{1}{c|}{ Max } \\
\hline IMIG_total & 10 & 358782.4 & 395159.6 & 30639 & 1269253 \\
\hline IMIG_RO & 10 & 25611.3 & 29230.56 & 525 & 87204 \\
\hline IMIG_RS & 10 & 723.5556 & 2024.253 & -2946 & 4747 \\
\hline ER_F & 10 & 61.52 & 5.852218 & 53.8 & 71.4 \\
\hline UR_F & 10 & 14.67 & 5.914962 & 5.7 & 26.3 \\
\hline GDP_cap & 10 & 34742.76 & 7742.028 & 22300 & 46800 \\
\hline POV & 10 & 20.36 & 4.894487 & 15.1 & 29.1 \\
\hline BERD & 10 & 1.35 & .5361022 & .52 & 2.205 \\
\hline ALMPs & 10 & .6627 & .4408053 & .184 & 1.631 \\
\hline PLMPs & 10 & 1.2265 & .6126924 & .0950001 & 2.093 \\
\hline EDU_S & 10 & 41.81 & 8.021422 & 24.7 & 57.1 \\
\hline EDU_T & 10 & 32.15 & 8.885724 & 16.2 & 46.8 \\
\hline GINI & 10 & 29.81 & 3.790178 & 24.8 & 36.7 \\
\hline HDI & 10 & .9051 & .0148507 & .886 & .928 \\
\hline Mat_Depriv & 10 & 35582.1 & 30177.08 & 5411 & 81126 \\
\hline Rep_life_satisf & 10 & 6.9660 & .5785 & 6.0613 & 7.8717 \\
\hline Att_relig_serv & 10 & 10.56 & 7.543238 & 2.2 & 27.3 \\
\hline Att_meet_political & 10 & 90.18 & 4.816362 & 79.2 & 96.2 \\
\hline Voluntar_educ & 10 & 12.83 & 4.485049 & 6.5 & 21.9 \\
\hline Job_sec & 10 & 92.21 & 1.784781 & 89 & 94.6 \\
\hline Soc_exclus & 10 & 6.46 & 2.38057 & 3.8 & 11.5 \\
\hline Job_discredit & 10 & 12.1 & 4.019121 & 7.8 & 18.8 \\
\hline Life_satisf & 10 & 7.52 & .5202564 & 6.6 & 8.2 \\
\hline Livingstand_satisf & 10 & 7.47 & .611101 & 6.6 & 8.3 \\
\hline
\end{tabular}

Source: Authors' process in Stata 